\title{
Seafloor geomorphology of western Antarctic Peninsula bays: a signature of ice flow behaviour
}

\author{
Yuribia P. Munoz and Julia S. Wellner \\ Department of Earth and Atmospheric Sciences, University of Houston, Houston, Texas 77204, USA \\ Correspondence: Yuribia P. Munoz (ypmunoz@uh.edu)
}

Received: 12 June 2017 - Discussion started: 22 June 2017

Revised: 4 November 2017 - Accepted: 13 November 2017 - Published: 22 January 2018

\begin{abstract}
Glacial geomorphology is used in Antarctica to reconstruct ice advance during the Last Glacial Maximum and subsequent retreat across the continental shelf. Analogous geomorphic assemblages are found in glaciated fjords and are used to interpret the glacial history and glacial dynamics in those areas. In addition, understanding the distribution of submarine landforms in bays and the local controls exerted on ice flow can help improve numerical models by providing constraints through these drainage areas. We present multibeam swath bathymetry from several bays in the South Shetland Islands and the western Antarctic Peninsula. The submarine landforms are described and interpreted in detail. A schematic model was developed showing the features found in the bays: from glacial lineations and moraines in the inner bay to grounding zone wedges and drumlinoid features in the middle bay and streamlined features and meltwater channels in the outer bay areas. In addition, we analysed local variables in the bays and observed the following: (1) the number of landforms found in the bays scales to the size of the bay, but the geometry of the bays dictates the types of features that form; specifically, we observe a correlation between the bay width and the number of transverse features present in the bays. (2) The smaller seafloor features are present only in the smaller glacial systems, indicating that short-lived atmospheric and oceanographic fluctuations, responsible for the formation of these landforms, are only recorded in these smaller systems. (3) Meltwater channels are abundant on the seafloor, but some are subglacial, carved in bedrock, and some are modern erosional features, carved on soft sediment. Lastly, based on geomorphological evidence, we propose the features found in some of the proximal bay areas were formed during a recent glacial advance, likely the Little Ice Age.
\end{abstract}

\section{Introduction}

While warming temperatures in the Antarctic Peninsula (AP) have resulted in the retreat of $90 \%$ of the regional glaciers (Cook et al., 2014) and the collapse of ice shelves (Morris and Vaughan, 2003; Cook and Vaughan, 2010), recent studies have shown that since the late 1990s this region is currently experiencing a cooling trend (Turner et al., 2016). The AP is a dynamic region that serves as a natural laboratory to study ice flow and the resulting sediment deposits. As the ice retreats, it leaves behind glacial geomorphic features on the seafloor; these submarine landforms have been mapped in glaciated environments in Antarctica (Anderson et al., 2001; Wellner et al., 2001, 2006; Evans et al., 2004; Heroy and Anderson, 2005; Larter et al., 2009; Livingstone et al., 2013; Hodgson et al., 2014), southern Chile (Dowdeswell and Vasquez, 2013), North America (Dowdeswell et al., 2016), and northern Europe (Ottesen et al., 2005; Ottesen and Dowdeswell, 2006, 2009; Dowdeswell et al., 2010), giving insight into the glacial history of each region. Several seafloor features have been mapped west of the AP on the continental slope and continental shelf (Dowdeswell et al., 2004; Graham and Smith, 2012; Gales et al., 2013), the South Shetland Islands (Milliken et al., 2009; Simms et al., 2011), South Georgia Island (Hodgson et al., 2014; Graham et al., 2017), Bransfield Strait (Canals et al., 2000, 2002), Gerlache Strait (Evans et al., 2004), south of Anvers Island (Domack et al., 2006), and Marguerite Bay (Ó Cofaigh et al., 2002; Anderson and Fretwell, 2008; Livingstone et al., 2013). However, the seafloor geomorphology in western AP bays has not been described in detail, except for a few locations (Garcia et al., 2016; Munoz and Wellner, 2016; Wölfl et al., 2016). Although most of the data we present are publicly available, this is the first instance, to our knowledge, 


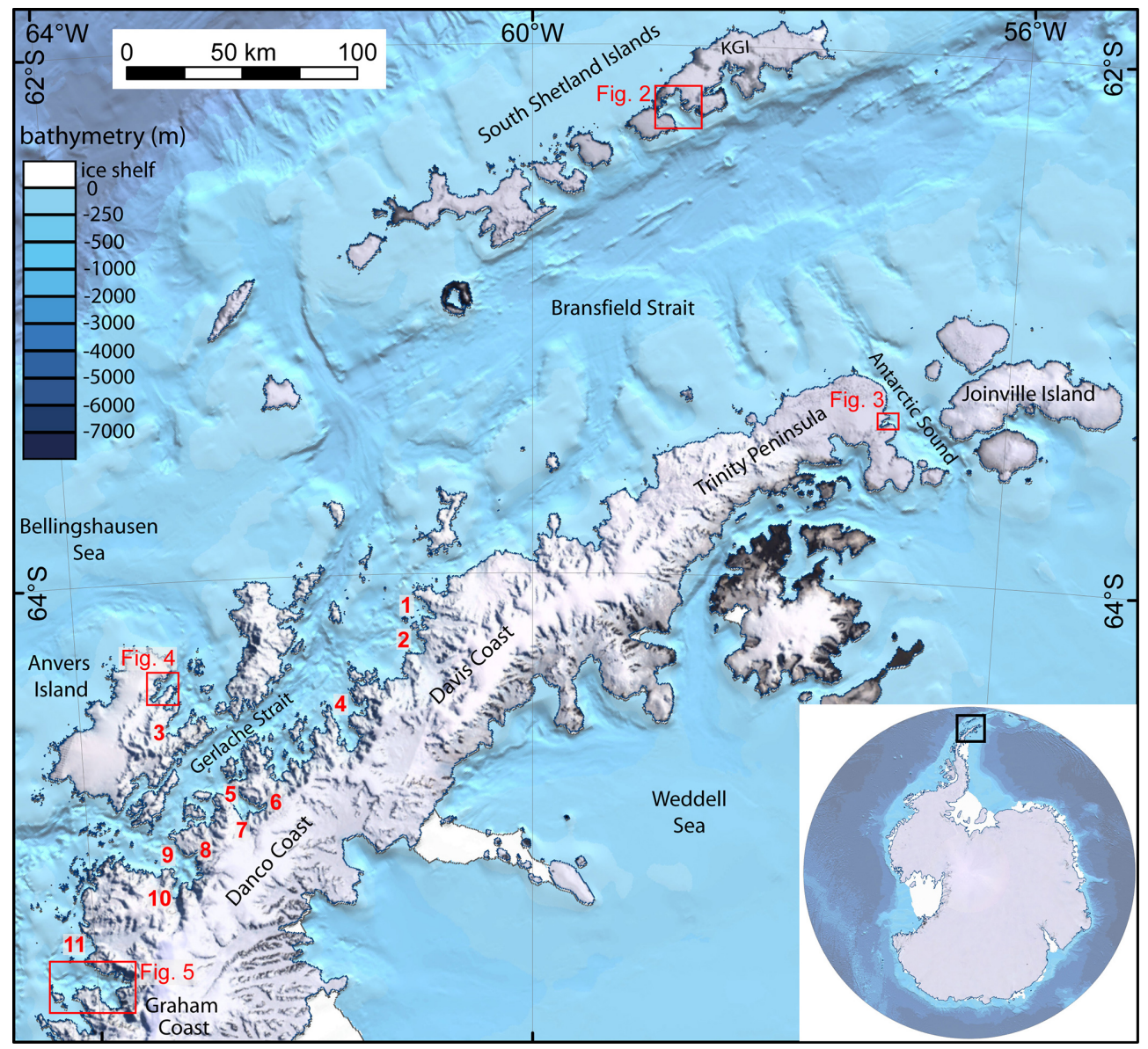

Figure 1. Map of the northern Antarctic Peninsula (AP) and South Shetland Islands; red boxes indicate Figs. 2-5. Inset shows the location of the AP in Antarctica. KGI: King George Island; (1) Cierva Cove, (2) Brialmont Cove, (3) Fournier Bay, (4) Charlotte Bay, (5) Andvord Bay, (6) Moser Glacier, (7) Lester Cove, (8) Briand Fjord, (9) Flandres Bay, (10) Etienne Fjord, and (11) Collins Bay. Individual maps of bays 1-11 found in the Supplement. AP map from Polar Geospatial Center; bathymetry and inset from IBCSO (Arndt et al., 2013).

that a detailed description of the seafloor geomorphology of a large number of western AP fjords has been completed.

We combine multibeam swath bathymetry data collected during seven cruises to the Antarctic Peninsula. The multibeam bathymetry data presented in this study expose geomorphic features formed during past ice flow in several bays in the western Antarctic Peninsula, the South Shetland Islands, and Anvers Island (Fig. 1). We focus this study on four bays throughout the AP: Maxwell Bay, located on King George Island (KGI), north of the AP; Hope Bay, located on the northernmost tip of the AP known as the Trinity Peninsula; Lapeyrère Bay, on Anvers Island, west of the AP; and finally Beascochea Bay, located in the Graham Land Coast of the western AP (Fig. 1). Data from additional bays throughout the AP (found in supplementary material) have been integrated in the results section to support this investigation. The glacial seafloor features reveal flow behaviour of grounded ice; structures formed in a deformable sedimentary substrate likely represent subglacial conditions shortly before ice decoupling from the seafloor, and structures in bedrock likely formed over several glacial-interglacial cycles (Wellner et al., 2001; Campo et al., 2017). We map the glacial landforms and analyse local variables including bay length and width, glacier drainage size flowing into the bays, seafloor lithology, and water depth in order to understand the controls of ice flow and retreat dynamics in these locations.

\section{Study area}

The AP is the northernmost extent of the Antarctic continent. The AP is a long $(\sim 1200 \mathrm{~km})$, thin $(\sim 250 \mathrm{~km})$ strip of mountains of up to $3500 \mathrm{~m}$ in elevation. The geological setting of the AP is characterized by Cenozoic tectonic extension and active volcanism (Griffith and Anderson, 1989). Glacial ice flow over crystalline bedrock has preferentially eroded over joints and faults, accentuating their appearance (Domack et al., 2006). The predominant rock types are metamorphic and intrusive and extrusive igneous rocks (Griffith and Anderson, 1989). Ice covers about $80 \%$ of the AP, where 


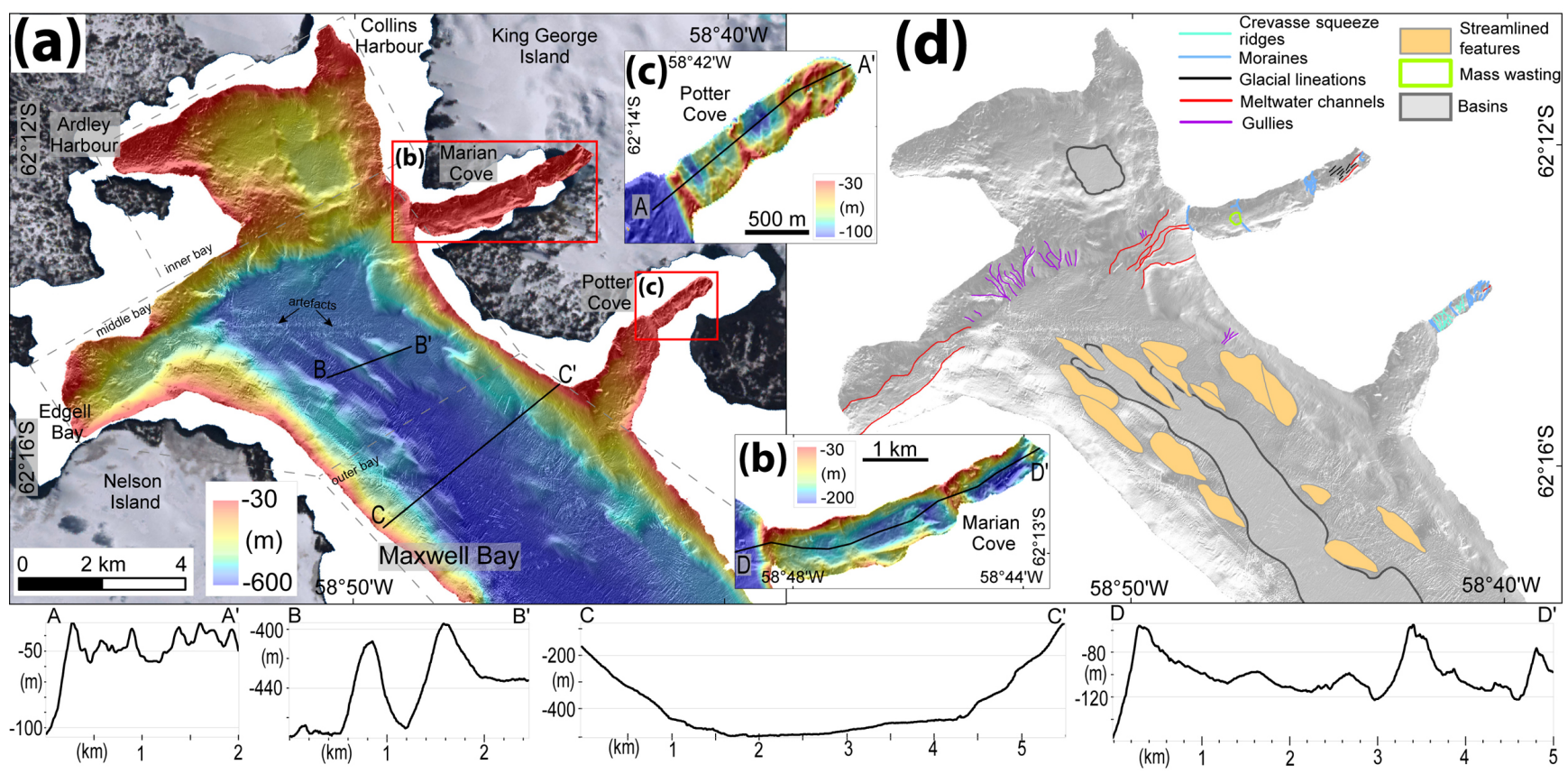

Figure 2. Multibeam swath bathymetry of Maxwell Bay (a), Marian Cove (b), and Potter Cove (c); vertical exaggeration is $5 \times$ in all images. (d) Interpretation of geomorphic features with hillshade as background. Cross sections $\mathrm{A}-\mathrm{A}^{\prime}$ and $\mathrm{D}-\mathrm{D}^{\prime}$ show transverse ridges in Potter Cove (c) and Marian Cove (b) respectively, B-B' shows elongated ridges in the bay, and $\mathrm{C}-\mathrm{C}^{\prime}$ shows the U-shaped fjord valley.

ice thickness ranges between 400 and $800 \mathrm{~m}$ (Fretwell et al., 2013) and averages about $500 \mathrm{~m}$. The ice cap covering Anvers Island reaches up to $600 \mathrm{~m}$, similar to the western AP (Ashley and Smith, 2000), while in KGI, the ice cap is only 150-200 m thick (Simms et al., 2011).

The high peaks of the AP form a topographic barrier to the westerly winds resulting in a warmer, wetter western AP, and a cooler, dryer eastern AP (Ó Cofaigh et al., 2014). The climate in Hope Bay (northern AP, Fig. 1) is cold, dry semipolar (Pereira et al., 2013). Annual air temperature at Esperanza Research Station (located in Hope Bay) range between -30.6 and $11.8^{\circ} \mathrm{C}$, with an average of $-5.1^{\circ} \mathrm{C}$ and an annual precipitation of $250 \mathrm{~mm}$ measured between 1952 and 2010 (Pereira et al., 2013; Schaefer et al., 2016). In contrast, the western AP receives an average of $1100 \mathrm{~mm} \mathrm{yr}^{-1}$, measured between 1997 and 2006 (Thomas et al., 2008), and up to $2900 \mathrm{~mm} \mathrm{yr}^{-1}$ in some bays (Fernandez et al., 2016). Annual air temperatures in the western AP vary between slightly above $0{ }^{\circ} \mathrm{C}$ in the summers to -8 to $-11^{\circ} \mathrm{C}$ in the winters (King et al., 2003). Sea ice covers the bays seasonally, but most areas are sea-ice-free during the summers (Domack and Ishman, 1993). The islands experience a maritime climate. KGI has a temperate to sub-polar glacial setting (Yoon et al., 2004), with few changes in air temperature throughout the year (average of $-1.8^{\circ} \mathrm{C}$, minimum of $-5.7^{\circ} \mathrm{C}$ in July, and maximum of $2{ }^{\circ} \mathrm{C}$ in January). Mean annual precipitation is about $1200 \mathrm{~mm}$ on the higher elevations but much less in areas like Potter Cove, where precipitation data in- dicate an annual average of $524 \mathrm{~mm}$ (Lee et al., 2008; KOPRI, 2014; Moon et al., 2015; Fernandez et al., 2016). On Anvers Island (west of the AP, Fig. 1), summer air temperatures reach up to $6-7.5^{\circ} \mathrm{C}$, while in the winter the average is $-5^{\circ} \mathrm{C}$ (Ashley and Smith, 2000). Precipitation in Anvers Island is on average approximately $1200 \mathrm{~mm}$ annually (Griffith and Anderson, 1989; Ashley and Smith, 2000) and up to $2000 \mathrm{~mm} \mathrm{yr}^{-1}$ in Lapeyrère Bay, northern Anvers Island (Fernandez et al., 2016).

\subsection{Maxwell Bay}

Maxwell Bay $\left(62^{\circ} 13.7^{\prime} \mathrm{S}, 58^{\circ} 50.9^{\prime} \mathrm{W}\right)$ (Fig. 2) is located in the western end of KGI. Maxwell Bay is about $15 \mathrm{~km}$ long, between 6 and $15 \mathrm{~km}$ wide, and has an approximate area of $140 \mathrm{~km}^{2}$. Maxwell Bay has several embayments: Edgell Bay, Ardley Harbour, Collins Harbour, Marian Cove (Fig. 2b), and Potter Cove (Fig. 2c). Water depths vary widely from $35 \mathrm{~m}$ in the inner bay to $500 \mathrm{~m}$ in the outer bay. The outer bay is Ushaped (Fig. 2, C-C'), with tens of metres of sediment cover (Milliken et al., 2009; Fernandez et al., 2016). The glacier catchment area around Maxwell Bay is about $92 \mathrm{~km}^{2}$, separated into four discrete glaciers. Collins Harbour, at the north end of Maxwell Bay, has a sediment accumulation rate of $5.5 \mathrm{~mm} \mathrm{yr}^{-1}$ (Boldt et al., 2013). 
Marian Cove $\left(62^{\circ} 12.8^{\prime} \mathrm{S}, 58^{\circ} 46.1^{\prime} \mathrm{W}\right)$ (Fig. $\left.2 \mathrm{~b}\right)$ is an elongated bay in northeastern Maxwell Bay. The bay is approximately $4 \mathrm{~km}$ long and between 1 and $1.5 \mathrm{~km}$ wide, with an approximate area of $5 \mathrm{~km}^{2}$. A single tidewater glacier (with a catchment area of about $15 \mathrm{~km}^{2}$ ) drains directly into the bay. This glacier retreated about $1.7 \mathrm{~km}$ between 1956 and 2013 (Lee et al., 2008; Moon et al., 2015). Large meltwater and sediment influx into the bay occur in the summer months (Moon et al., 2015). Sediment accumulation rates vary between 5.2 and $6.6 \mathrm{~mm} \mathrm{yr}^{-1}$ in Marian Cove (Boldt et al., 2013).

Potter Cove $\left(62^{\circ} 13.9^{\prime} \mathrm{S}, 58^{\circ} 41.2^{\prime} \mathrm{W}\right)$ (Fig. 2c) is an elongated bay in southeastern Maxwell Bay. Potter Cove is approximately $4 \mathrm{~km}$ long and between $1 \mathrm{~km}$ wide in the bay head and $2.5 \mathrm{~km}$ wide in the bay mouth, approximately $7 \mathrm{~km}^{2}$ in total area, and with water depths ranging between 25 and $150 \mathrm{~m}$. Fourcade Glacier drains directly into this bay, but most of it terminates on land. The glacier catchment area is about $20 \mathrm{~km}^{2}$. Ice front retreat of Fourcade Glacier has been approximately $1 \mathrm{~km}$ in Potter Cove between 1956 and 2008 (Wölfl et al., 2016), with a greater retreat of grounded ice in the tidewater part of glacier and much less on the land-based grounded ice (Ruckamp et al., 2011). Meltwater discharges are common in Potter Cove, especially during the summer (Wölfl et al., 2014), with sediment accumulation rates in outer Potter Cove of $1.6 \mathrm{~mm} \mathrm{yr}^{-1}$ (Boldt et al., 2013).

\subsection{Hope Bay}

Hope Bay $\left(63^{\circ} 24.4^{\prime} \mathrm{S}, 57^{\circ} 2.8^{\prime} \mathrm{W}\right)$ (Fig. 3) is located along the northernmost tip of the Antarctic Peninsula, draining into the Antarctic Sound. The bay is $6 \mathrm{~km}$ long, and between $800 \mathrm{~m}$ wide in the bay head and $3 \mathrm{~km}$ wide in the bay mouth; the bay area is about $11.5 \mathrm{~km}^{2}$. Water depths in Hope Bay vary between 50 and $320 \mathrm{~m}$. Two large glaciers drain directly into the bay: Depot Glacier (catchment area of $7 \mathrm{~km}^{2}$ ) and Arena Glacier (catchment area of $16 \mathrm{~km}^{2}$ ). In addition, three unnamed glaciers (each with an average area of $3 \mathrm{~km}^{2}$ ) also discharge into Hope Bay. Boldt et al. (2013) measured a sediment accumulation rate of $3 \mathrm{~mm} \mathrm{yr}^{-1}$ in Hope Bay.

\subsection{Lapeyrère Bay}

Lapeyrère Bay $\left(64^{\circ} 25.3^{\prime} \mathrm{S}, 63^{\circ} 17^{\prime} \mathrm{W}\right)$ (Fig. 4) is located in northeastern Anvers Island. Lapeyrère Bay is a narrow, elongated bay with water depths varying from 250 to $740 \mathrm{~m}$. The bay is $11 \mathrm{~km}$ long, $2 \mathrm{~km}$ wide in the bay head and $3.5 \mathrm{~km}$ in the bay mouth, with an overall bay area of $32 \mathrm{~km}^{2}$. One large glacier, Iliad Glacier (catchment area of $234 \mathrm{~km}^{2}$ ), drains into the bay, in addition to other smaller glaciers around the perimeter of the bay, each with an average catchment area of $6 \mathrm{~km}^{2}$. Sediment accumulation rates in Lapeyrère Bay are 2.2-3.2 $\mathrm{mm} \mathrm{yr}^{-1}$ (Boldt et al., 2013).

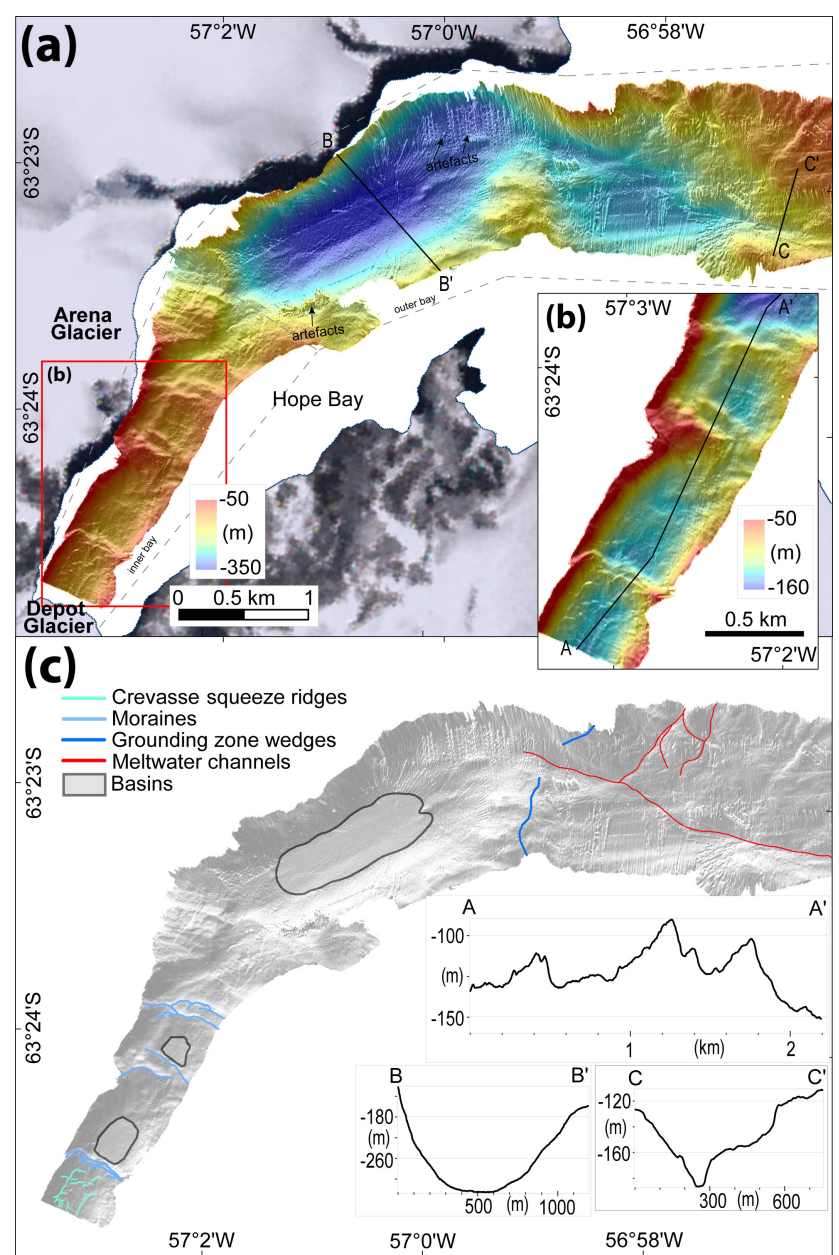

Figure 3. Multibeam swath bathymetry of Hope Bay (a), the inner bay area (b), and interpretation of geomorphic features with hillshade as background (c). Transverse ridges can be seen in $\mathrm{A}-\mathrm{A}^{\prime}$, the $\mathrm{U}$-shaped fjord valley is seen in $\mathrm{B}-\mathrm{B}^{\prime}$, and a meltwater channel in the outer bay $\left(C-C^{\prime}\right)$. Vertical exaggeration is $3 \times$ in all images.

\subsection{Beascochea Bay}

Beascochea Bay $\left(65^{\circ} 31^{\prime} \mathrm{S}, 63^{\circ} 52.2^{\prime} \mathrm{W}\right)$ (Fig. 5) is the southernmost bay presented in this study. It is an elongated bay with several embayments in the bay head, three of them described below. Each one of the described embayments has a large glacier draining directly into it. None of the coves are named and, therefore, for the purposes of this paper, we use the names of the glaciers to identify the coves: Lever Glacier cove, Funk Glacier cove, and Cadman Glacier cove. Beascochea Bay is approximately $24 \mathrm{~km}$ long, $6-13 \mathrm{~km}$ wide, with an approximate bay area of $235 \mathrm{~km}^{2}$. Several glaciers drain into this bay along its perimeter; their individual catchment area varies between 1 and $28 \mathrm{~km}^{2}$. Sediment accumulation rates in Beascochea Bay vary between 2.2 and $7 \mathrm{~mm} \mathrm{yr}^{-1}$ (Boldt et al., 2013). 


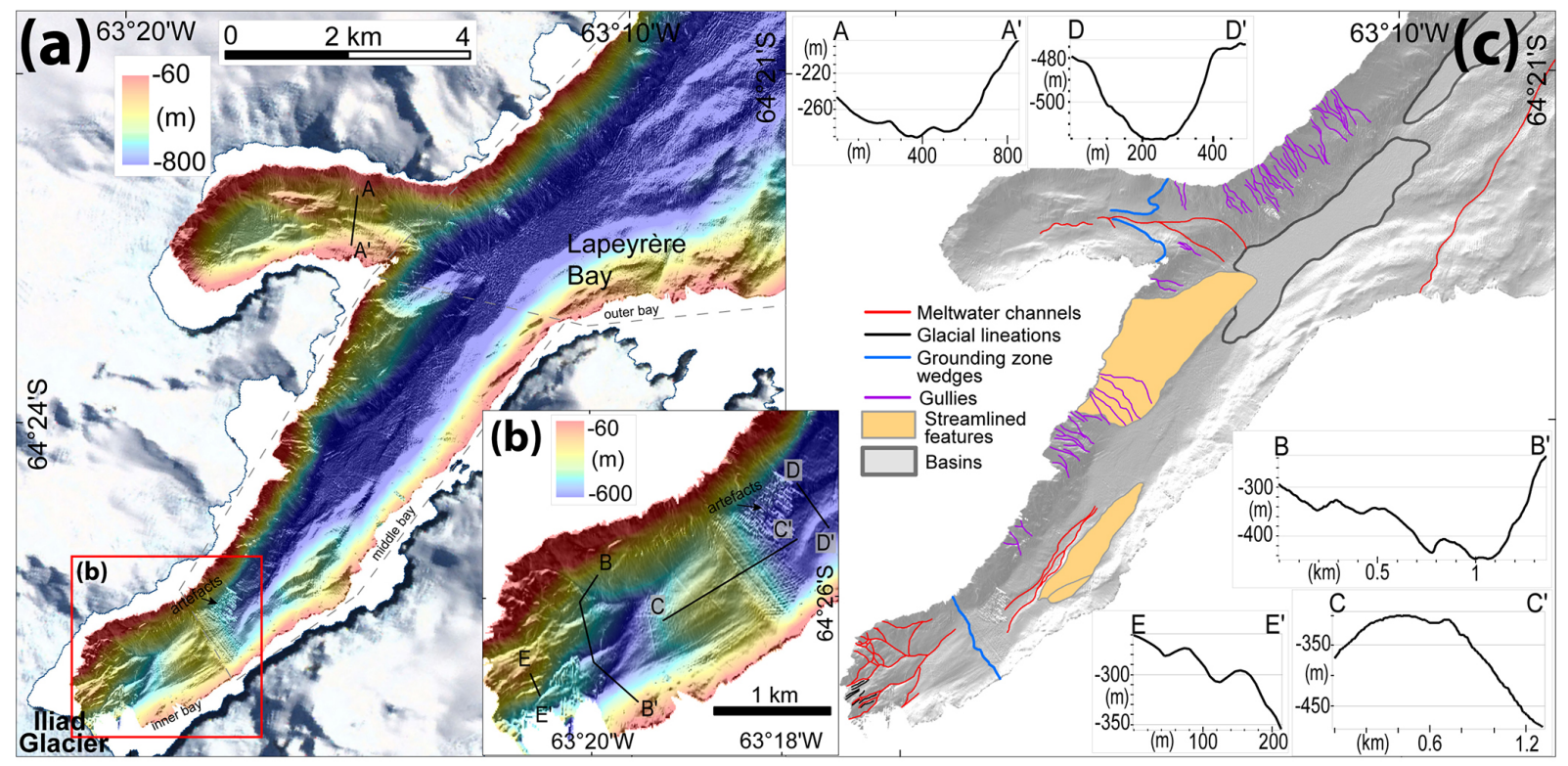

Figure 4. Multibeam swath bathymetry of Lapeyrère Bay (a), the inner bay area (b), and the interpretation of geomorphic features with hillshade as background (c). Cross sections $\mathrm{A}-\mathrm{A}^{\prime}, \mathrm{B}-\mathrm{B}^{\prime}$, and D- $\mathrm{D}^{\prime}$ show meltwater channels around the bay, $\mathrm{C}-\mathrm{C}^{\prime}$ shows the grounding zone wedge in the inner bay, and $\mathrm{E}-\mathrm{E}^{\prime}$ shows glacial lineations in the inner bay area. Vertical exaggeration is $5 \times$ in panel (a) and $3 \times$ in panel (b).

Lever Glacier cove $\left(65^{\circ} 30.7^{\prime} \mathrm{S}, 63^{\circ} 43.4^{\prime} \mathrm{W}\right)$ (Fig. $\left.5 \mathrm{~b}\right)$ is an elongated bay, $6 \mathrm{~km}$ long and $3 \mathrm{~km}$ wide, with a total bay area of about $16 \mathrm{~km}^{2}$. The largest glacier draining into this cove is Lever Glacier (catchment area of $177 \mathrm{~km}^{2}$ ), while other glaciers draining into the bay are much smaller (individual average area is about $\left.4 \mathrm{~km}^{2}\right)$. Funk Glacier cove $\left(65^{\circ} 34.8^{\prime} \mathrm{S}\right.$, $63^{\circ} 45.4^{\prime} \mathrm{W}$ ) (Fig. 5c) is an elongated bay, $4 \mathrm{~km}$ long and $2 \mathrm{~km}$ wide, with a total bay area of about $8 \mathrm{~km}^{2}$. A large glacier drains directly into this cove, Funk Glacier, with a surface area of $158 \mathrm{~km}^{2}$. Another small glacier, with a surface area of $3 \mathrm{~km}^{2}$, also flows into the cove. During the late 1960s, this cove was covered by ice (Cook et al., 2014). Although it is unclear whether the ice cover was grounded ice or permanent sea ice, the fact that this area has alternated between ice-free and ice-covered since the late 1960s suggests fast sea ice cover and not grounded ice. Cadman Glacier cove $\left(65^{\circ} 36.7^{\prime} \mathrm{S}, 63^{\circ} 48.7^{\prime} \mathrm{W}\right.$ ) (Fig. 5c) is the smallest cove surveyed in Beascochea Bay; it is $3 \mathrm{~km}$ long and $3 \mathrm{~km}$ wide, and the total bay area is about $9 \mathrm{~km}^{2}$. One large glacier drains directly into this cove, Cadman Glacier, with a surface area of $307 \mathrm{~km}^{2}$.

\section{Methods}

Multibeam swath bathymetry data were collected on multiple research expeditions to the western AP aboard the RV/IB Nathaniel B. Palmer (NBP0201, NBP0502, NBP0602A, NBP0703, NBP1001, and NBP1203) and the RV/IB Araon (ARA1304). Multibeam soundings were collected in a swath perpendicular to the ship track using a hull- mounted Kongsberg EM120 multibeam echosounder, with a swath of 191 beams, operating at a frequency of $12 \mathrm{kHz}$ on the NBP cruises and Kongsberg EM122, with a swath of 432 beams, operating at a frequency of $12 \mathrm{kHz}$ on the ARA cruise. These data sets were merged using CARIS HIPS \& SIPS where the survey data were manually edited to remove anomalous readings and gridded to create relief maps. Grids were created per bay at resolutions of $25 \mathrm{~m}$ and in some cases $10 \mathrm{~m}$. Here we show the optimal resolution of the data, which in most cases is the $25 \mathrm{~m}$ grid. These grids were then imported into ArcGIS 10, where hillshade effect was created with a $z$ factor $>1$ to simulate vertical exaggeration. This compilation of bathymetry in addition to other data sets have recently been published in Boldt et al. (2013) and Lavoie et al. (2015). In addition to mapping the submarine landforms, we compare them to the local physiographic variables of each bay including latitude, area, length, width, glacier catchment area, and the seafloor lithology based on CHIRP results, to understand controls on ice flow behaviour. High-resolution shallow sub-bottom CHIRP profiles were collected during NBP0703 throughout the study area. The data were collected using a hull-mounted Knudsen $320 \mathrm{~B} / \mathrm{R}$ with a frequency of $3.5 \mathrm{kHz}$ and have been interpreted using SMT Kingdom software. CHIRP sonar provides a vertical resolution of about $1 \mathrm{~m}$ and can image unconsolidated sediments up to $100 \mathrm{~m}$ below the seafloor. The CHIRP data were used to identify seafloor lithology (sediment type or bedrock) and the thickness of sedimentary units. 


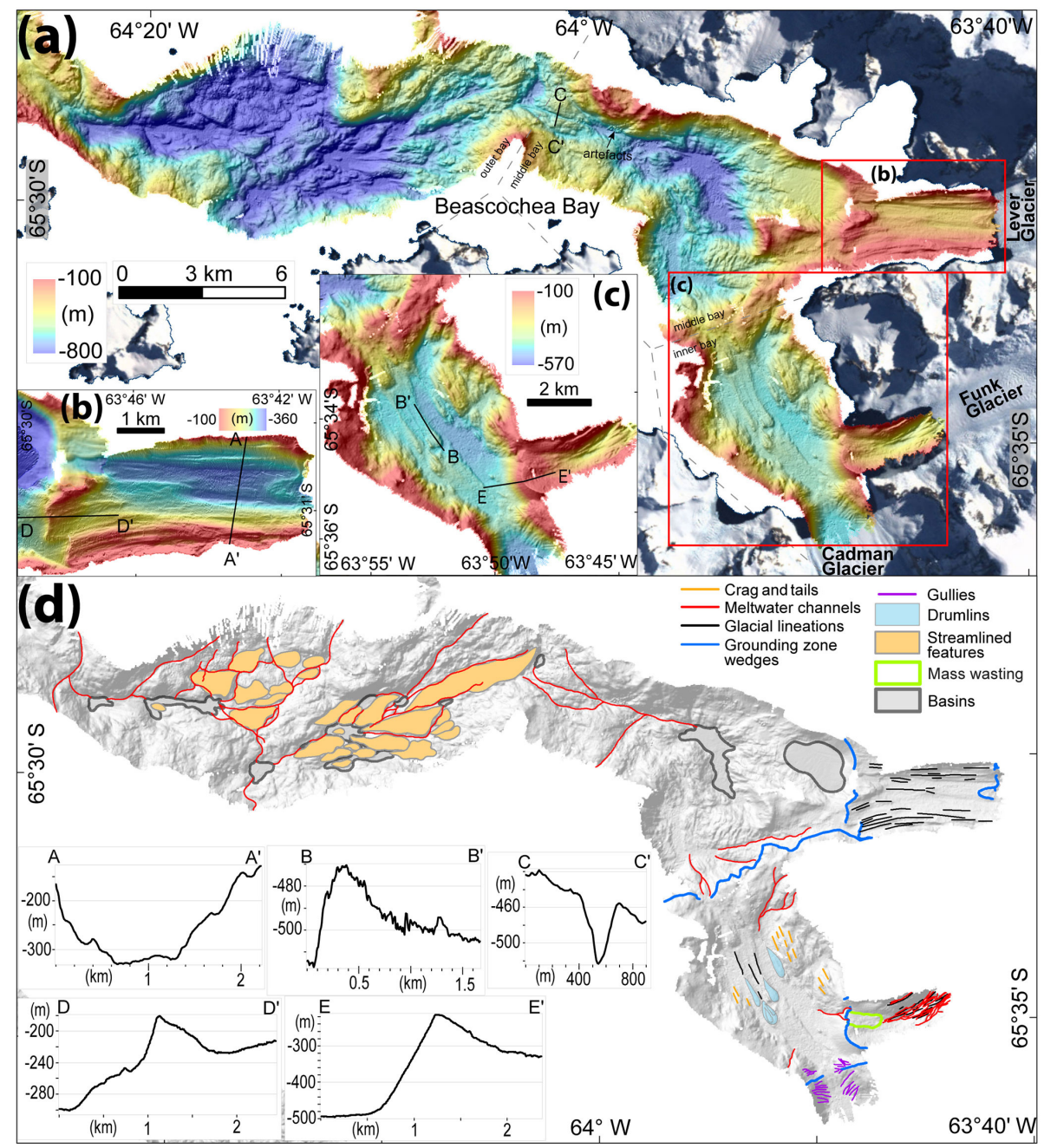

Figure 5. Multibeam swath bathymetry of Beascochea Bay (a), Lever Glacier cove (b), the inner bay area (c), and the interpretation of geomorphic features with hillshade as background (d). A- $\mathrm{A}^{\prime}$ shows glacial lineations in Lever Glacier cove, B- ${ }^{\prime}$ shows a drumlin in the inner bay area, $\mathrm{C}-\mathrm{C}^{\prime}$ shows the cross-section profile of a meltwater channel, and $\mathrm{D}-\mathrm{D}^{\prime}$ and $\mathrm{E}-\mathrm{E}^{\prime}$ show large transverse ridges. Vertical exaggeration is $3 \times$ in all images.

\section{Bathymetry results}

We describe the seafloor landforms identified in the bays of the western AP. Figure 6 shows some of these individual landforms mapped on the seafloor and Table 1 lists the criteria for identification in this study. The interpreted CHIRP facies are shown in Fig. 7. Maps of interpreted seafloor features throughout individual bays are shown in Figs. 2-5 and S1-S7 in the Supplement. In addition, data in Tables S1 and S2 in the Supplement show the bay location, length, width, area, number of glaciers in each bay, total glacier catchment area, and the submarine landforms found in each bay.

\subsection{Maxwell Bay}

The seafloor in northern Maxwell Bay (Fig. 2), near Collins Harbour and Ardley Harbour, is a large, shallow platform with water depths up to $280 \mathrm{~m}$. Water depths increase rapidly to $>400 \mathrm{~m}$ in the middle of the bay, where gullies and channels that cut into the seafloor can be found. Meltwater channels (1-4 km long, $10-30 \mathrm{~m}$ wide, and 1-2 m deep) are present on the seafloor from Edgell Bay and from Marian Cove, trending towards the middle of Maxwell Bay. Large promontories are located between King George Island and Nelson Island. A few elongated hills, parallel to the bay axis, are present in the middle of the bay (Fig. 2, B-B'). These seamounts range in length of $1-2.5 \mathrm{~km}$, a maximum width of 200-800 m, and a maximum height of 10-50 m. Sediment thickness in the outer bay are in excess of $100 \mathrm{~m}$ (Milliken et al., 2009), and therefore other features carved by flowing ice in this area, if any, are buried. Simms et al. (2011) described a large sediment fan at the mouth of Maxwell Bay, draining out of the bay into the Bransfield Strait. The fan has a sed- 
Table 1. Geomorphic features mapped and criteria for identification.

\begin{tabular}{|c|c|c|c|c|}
\hline Glacial landform & Defining characteristics & $\begin{array}{l}\text { Dimensions } \\
\text { min-max (metres) } \\
\text { length, width, height }\end{array}$ & Formation interpretation & Example \\
\hline $\begin{array}{l}\text { Crevasse squeeze } \\
\text { ridge }\end{array}$ & $\begin{array}{l}\text { Small, short ridges, cross-cutting } \\
\text { each other or isolated }\end{array}$ & $30-300,10-30,1-3$ & $\begin{array}{l}\text { Depositional, formed in } \\
\text { crevassed glacier terminus }\end{array}$ & Fig. $6 \mathrm{~g}$ \\
\hline Moraine & $\begin{array}{l}\text { Transverse ridge, found individually } \\
\text { or amalgamated }\end{array}$ & $250-1000,100-300,8-30$ & $\begin{array}{l}\text { Depositional, formed in front } \\
\text { of glacier terminus during short } \\
\text { episode of ice stability }\end{array}$ & Fig. $6 \mathrm{~g}$ \\
\hline $\begin{array}{l}\text { Grounding zone } \\
\text { wedge }\end{array}$ & $\begin{array}{l}\text { Transverse ridge, wedge shaped, } \\
\text { steep distal and gentler proximal side }\end{array}$ & $800-8000,80-2500,10-130$ & $\begin{array}{l}\text { Depositional, formed in front } \\
\text { of glacier terminus during } \\
\text { long episode of ice stability }\end{array}$ & Fig. 6e \\
\hline Glacial lineation & $\begin{array}{l}\text { Elongated, symmetric, parallel to } \\
\text { semi-parallel ridge (to one another } \\
\text { and to bay length) }\end{array}$ & $80-2700,5-200,1-20$ & $\begin{array}{l}\text { Depositional or erosional, } \\
\text { formed by ice ploughing }\end{array}$ & Fig. $6 \mathrm{a}$ \\
\hline Drumlin & $\begin{array}{l}\text { Teardrop shaped with tail, } \\
\text { formed in deformable sediment }\end{array}$ & $500-1200,60-380,5-30$ & $\begin{array}{l}\text { Depositional or erosional, } \\
\text { formed in glaciogenic sediment }\end{array}$ & Fig. $6 \mathrm{c}$ \\
\hline Crag and tail & $\begin{array}{l}\text { Teardrop shaped or large } \\
\text { bedrock protrusion with tail, } \\
\text { parallel to semi-parallel } \\
\text { (to one another and to bay length) }\end{array}$ & $130-900,40-300,2-28$ & $\begin{array}{l}\text { Depositional or erosional, } \\
\text { formed in till or bedrock }\end{array}$ & Fig. 6d \\
\hline Streamlined feature & $\begin{array}{l}\text { Elongated hill formed in bedrock, } \\
\text { symmetric to asymmetric }\end{array}$ & $260-5000,130-1200,8-220$ & Erosional, formed in bedrock & Fig. $6 \mathrm{~b}$ \\
\hline Meltwater channel & $\begin{array}{l}\text { Linear to sinuous channels, formed } \\
\text { in bedrock or sedimentary unit, } \\
\text { found individually or in networks, } \\
\text { abrupt initiation and termination points }\end{array}$ & $270-7000,8-800,1-120$ & $\begin{array}{l}\text { Erosional, formed in bedrock } \\
\text { or sedimentary units }\end{array}$ & Fig. 6d \\
\hline
\end{tabular}

iment thickness of up to $1000 \mathrm{~m}$ and it is located in water depths between 400 and $1400 \mathrm{~m}$.

The seafloor topography of Marian Cove (Fig. 2b) is characterized by transverse ridges in the bay (Fig. 2, D-D'). Three major transverse ridges divide the bay into a proximal, middle, and outer basin. The proximal basin is the deepest, up to $135 \mathrm{~m}$ depth compared to $120 \mathrm{~m}$ and 110 in the middle and outer basin respectively. The outer, most distal transverse ridge separates Marian Cove from Maxwell Bay. This feature is at least $650 \mathrm{~m}$ long, $200 \mathrm{~m}$ wide, and $20 \mathrm{~m}$ high. Although this feature is found across the width of the bay, water depth varies along the ridge crest from $40 \mathrm{~m}$ in the north to $70 \mathrm{~m}$ in the south. The middle ridge (approximately $1 \mathrm{~km}$ long, $100 \mathrm{~m}$ wide, and $8 \mathrm{~m}$ high) appears breached, with a possible slope failure deposit located on the west side of the ridge. Unfortunately, the resolution of the data is not clear enough to fully resolve this feature. However, the deposits have a fan shape and the water depths are shallower in this area, indicating a likely mass wasting deposit. The inner, most proximal ridge (approximately $500 \mathrm{~m}$ long, $300 \mathrm{~m}$ wide, and between 20 and $30 \mathrm{~m}$ high) is wider than the other two and it could possibly be an amalgamation of more than one ridge. The data show hints of other, smaller ridges across the bay, located between the larger ridges, but these are not resolved due to the low resolution of the data. The inner (most proximal) basin seafloor shows elongated (80-340 m long), narrow hills (10$35 \mathrm{~m}$ wide, $1-2 \mathrm{~m}$ high), parallel to the bay axis and unevenly spaced. Lastly, a topographic high, about $250 \mathrm{~m}$ long, $200 \mathrm{~m}$ wide, and $15 \mathrm{~m}$ high, is located on the eastern end of the surveyed area, close to the modern ice front where a meltwater channel is identified. This feature is about $430 \mathrm{~m}$ long, $20 \mathrm{~m}$ wide, and $2 \mathrm{~m}$ deep.

Potter Cove (Fig. 2c) is separated from Maxwell Bay by a shallow sill, approximately $130 \mathrm{~m}$ wide and $12 \mathrm{~m}$ high. The seafloor geomorphology in Potter Cove is characterized by numerous transverse features (Fig. 2, A-A'). Although the multibeam survey covers a small portion of the bay (Fig. 2a), transverse ridges across the bay are abundant in the data set. We have classified the transverse ridges into two sets: (1) continuous ridges across the width of the surveyed area and individual ridges symmetrical in cross-section profile, approximately 300-400 m long, 100-160 m wide, and 10$14 \mathrm{~m}$ high; and (2) semi-continuous ridges, semi-transverse to the cove, some cross-cutting each other, in which individual ridges are approximately 50-300 $\mathrm{m}$ long, 15-30 m wide, and 1-3 $\mathrm{m}$ high, with jagged crests and symmetrical crosssection profiles, located between the larger transverse ridges. Unlike the discrete transverse ridges in the mouth of the 


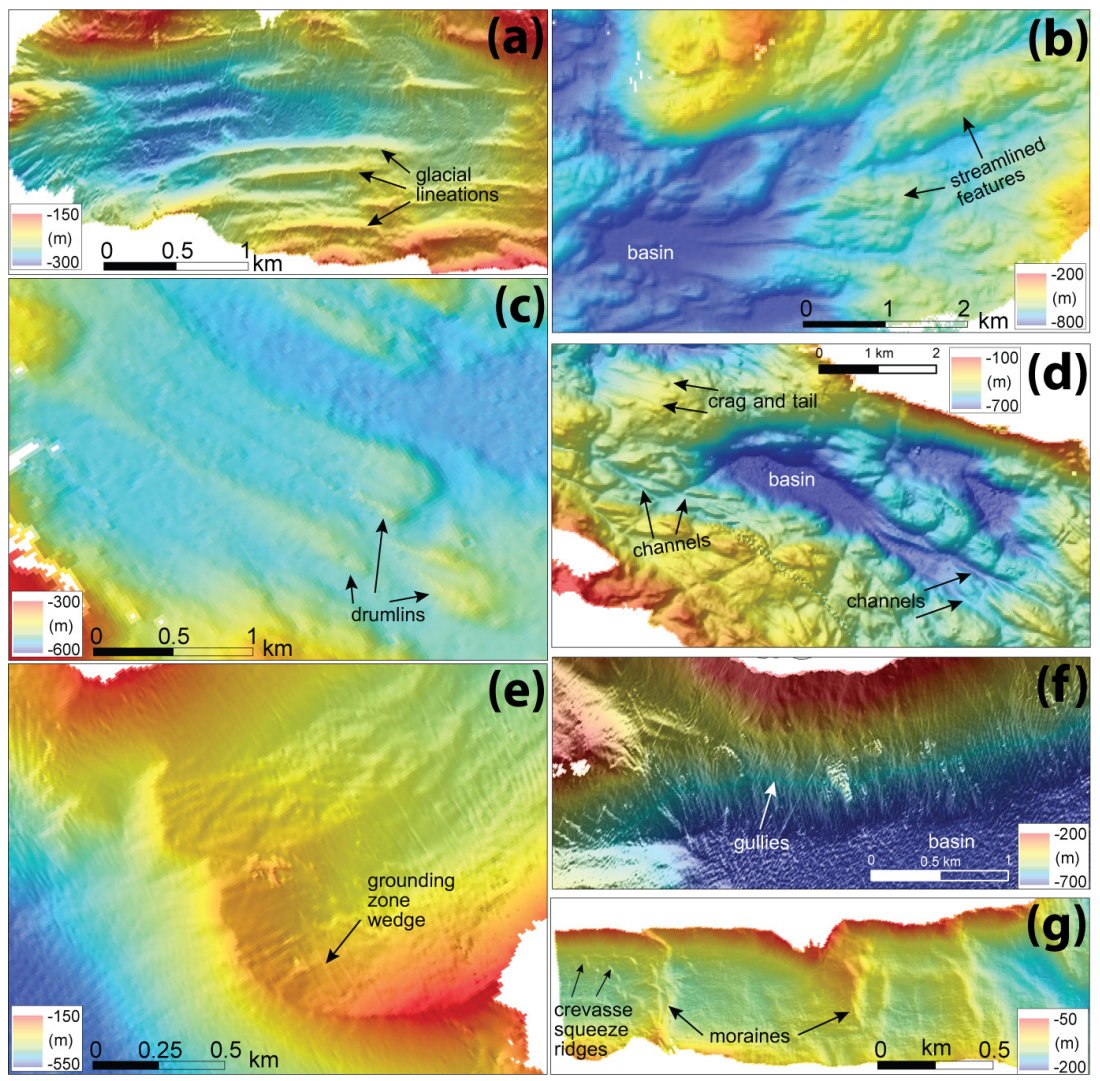

Figure 6. Seafloor landforms found in the bays of the western Antarctic Peninsula: (a) glacial lineations, (b) streamlined features and basin, (c) drumlins, (d) crag and tails, meltwater channels, and basin, (e) grounding zone wedge, (f) gullies and basin, and (g) moraines and crevasse squeeze ridges.

bay, ridges proximal to the head of the bay are arcuate and breached by a meltwater channel ( $280 \mathrm{~m}$ long, $8 \mathrm{~m}$ wide, and about $1 \mathrm{~m}$ deep).

\subsection{Hope Bay}

The seafloor in inner Hope Bay (Fig. 3) is characterized by several transverse ridges (Fig. $3 \mathrm{~b}, \mathrm{~A}-\mathrm{A}^{\prime}$ ), while the outer bay is characterized by a large, deep basin (Fig. 3, B-B'). Three sets of transverse ridges are present in the inner bay. Each one of these sets of ridges appears as a composite feature of more than one ridge stacked on or near one another. The most distal set of transverse ridges is at least $630 \mathrm{~m}$ long across inner Hope Bay, approximately $200 \mathrm{~m}$ wide, and $15 \mathrm{~m}$ high. The next set is $560 \mathrm{~m}$ long, with a width of up to $300 \mathrm{~m}$ and height ranging $10-20 \mathrm{~m}$. The most proximal set of ridges measure $500 \mathrm{~m}$ long, $160 \mathrm{~m}$ wide, and $10 \mathrm{~m}$ high. The location of the proximal ridges matches the ice extent mapped in the late 1950s (from Cook et al., 2014), which suggests ice was grounded at this site forming the transverse ridges. The seafloor between the proximal set of transverse ridges and the modern ice front is covered by a series of discrete, arcuateshaped ridges, some cross-cutting each other. The individual ridges are on average $30 \mathrm{~m}$ long (but up to $260 \mathrm{~m}$ in one case),
10-25 $\mathrm{m}$ wide, and 1-3 $\mathrm{m}$ high. These features have a symmetrical cross-section profile. Two large promontories separate the inner bay from the outer bay, immediately followed by a large $\left(2 \mathrm{~km}^{2}\right.$ area) flat-bottomed basin. The outer bay is separated from the Antarctic Sound by a transverse bathymetric high, only partially surveyed, which is cut through by a meltwater channel ( $50 \mathrm{~m}$ deep, $300 \mathrm{~m}$ wide) that trends towards the Antarctic Sound (Fig. 3, C-C').

\subsection{Lapeyrère Bay}

The seafloor in front of Iliad Glacier in Lapeyrère Bay (Fig. 4b) is characterized by poorly defined, elongated features (Fig. 4, E-E') and numerous meltwater channels (Fig. 4, $\left.\mathrm{B}-\mathrm{B}^{\prime}\right)$. The elongated features are symmetrical, approximately 180-300 m long, $40 \mathrm{~m}$ wide, and $10 \mathrm{~m}$ high. The meltwater channels trend from the ice front margin towards the middle of the inner Lapeyrère Bay, separated from the middle and outer bay by a large transverse ridge (Fig. 4, C-C'). The meltwater channel lengths vary between 1.2 and $2.5 \mathrm{~km}$, channel widths are up to $200 \mathrm{~m}$, and channel depths are 10$30 \mathrm{~m}$. The transverse ridge is located $2.5 \mathrm{~km}$ from the Iliad Glacier front. The ridge is approximately $3 \mathrm{~km}$ long and $60 \mathrm{~m}$ high; width varies along the ridge, from $500 \mathrm{~m}$ near the bay 

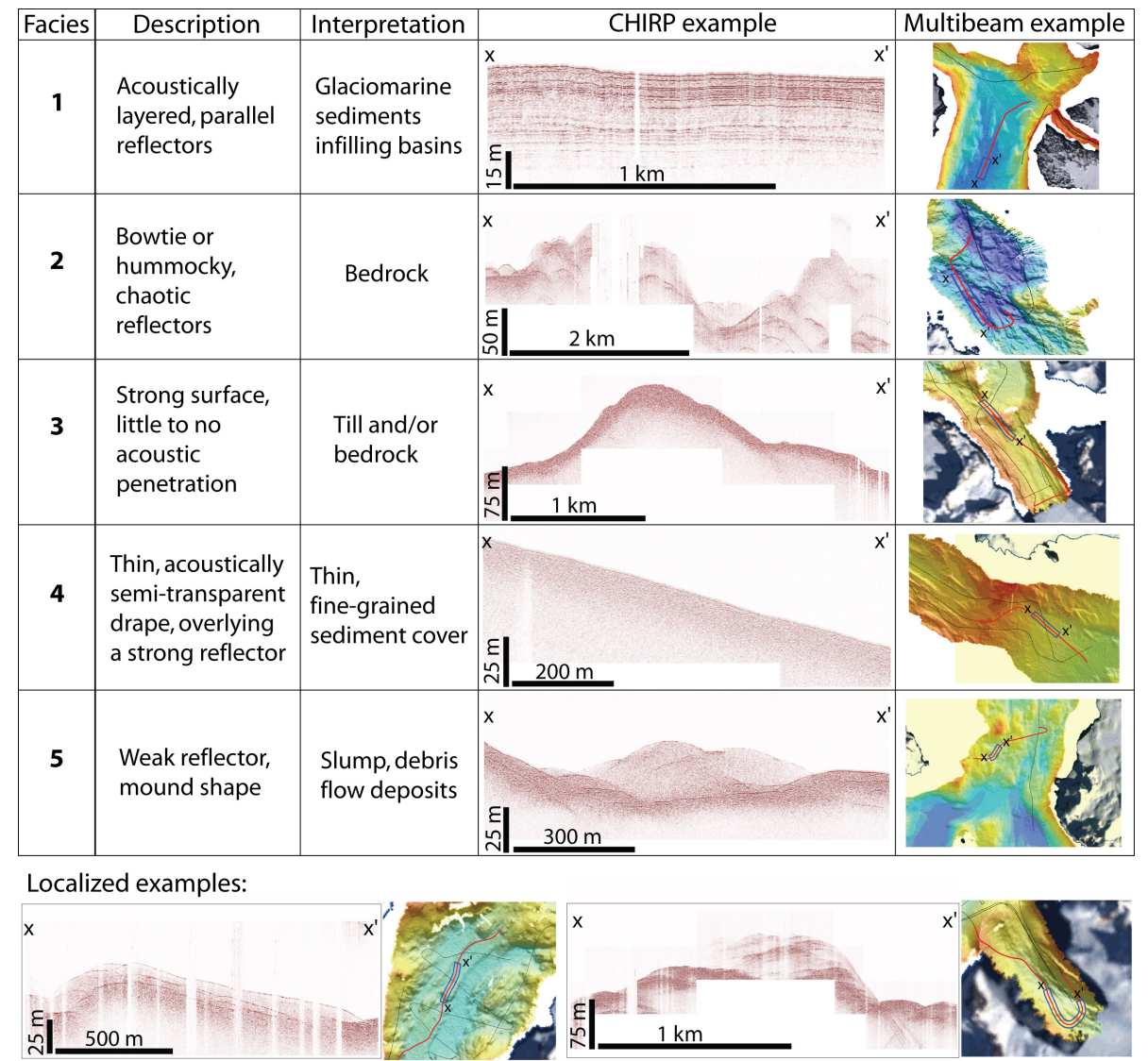

(a) Asymmetric wedge with reflectors:

(b) Stacked sediment packages: thin sediment cover, drumlin

channel-glacial lineation pair, near ice front

Figure 7. CHIRP facies showing seafloor lithology. Five facies were identified throughout the bay; in addition, two localized examples of features are shown: (a) drumlin and (b) glacial lineations near the modern ice front. The blue rectangle in multibeam example shows the location of the chirp example shown.

walls to $2500 \mathrm{~m}$ in the middle of the inner bay. The ridge has an asymmetrical cross-section profile (Fig. $4, \mathrm{C}-\mathrm{C}^{\prime}$ ), with a gentle slope on the proximal side and steeper slope on the distal side. A long $(5 \mathrm{~km})$ meltwater channel emerges from the distal side of the transverse ridge and trends towards the middle of the bay (Fig. 4, D- $\mathrm{D}^{\prime}$ ). The channel is wide $(300 \mathrm{~m})$, with steep walls and a flat base $30 \mathrm{~m}$ deep. An elongated ridge is present in the middle bay, parallel to the bay axis. The ridge is about $2.2 \mathrm{~km}$ long, up to $400 \mathrm{~m}$ wide, and $220 \mathrm{~m}$ high. The seafloor in the middle and outer Lapeyrère Bay is smooth and gently dipping towards the outer bay. Abundant slope failures are observed on the steep walls of the fjord. A small, unnamed embayment $(5 \mathrm{~km}$ long, $2 \mathrm{~km}$ wide) is located on northwestern Lapeyrère Bay. An unnamed glacier, with a catchment area of $57 \mathrm{~km}^{2}$, drains into this unnamed embayment. A sinuous ridge, transverse to ice flow, now breached by meltwater channels and slope failures (Fig. 4, A-A'), is present in the embayment mouth. The transverse ridge has an asymmetrical cross-section profile, it is $2.5 \mathrm{~km}$ long, $100 \mathrm{~m}$ wide, and up to $70 \mathrm{~m}$ high.

\subsection{Beascochea Bay}

The inner bay area (Fig. 5c), at the convergence of Cadman and Funk glaciers, is separated from the middle bay by an elongated feature, transverse to the bay length. The ridge is about $8 \mathrm{~km}$ long, $220 \mathrm{~m}$ high, and up $1 \mathrm{~km}$ wide. Some areas along this mount are rugged, possibly indicating bedrock. The features present in inner Beascochea Bay are drumlins, glacial lineations, and crag-and-tail landforms. Drumlins are teardrop shaped, 600-1400 m long, 200-380 m wide, and 20-30 m high. The steep lee side points towards Cadman Glacier and the gentler, stoss side points towards the transverse ridge (Fig. 5, B-B'). CHIRP data show these are sedimentary features (Fig. 7a). The drumlins are immediately followed by glacial lineations, located at the gentler end of the drumlins. These elongated landforms are 240 $2600 \mathrm{~m}$ long, 30-170 $\mathrm{m}$ wide, and $2-10 \mathrm{~m}$ high. Crag-andtail landforms are located peripherally to the drumlins and lineations, along the bay walls. These elongated features are 200-500 m long, 60-120 m wide, and 10-15 m high, and formed by a bedrock knob with a tail of sediment. Middle 
Beascochea Bay is characterized by a rugged seafloor with linear meltwater channels (Fig. $\left.5, \mathrm{C}-\mathrm{C}^{\prime}\right)$ and large $\left(2.5 \mathrm{~km}^{2}\right)$, deep $(240 \mathrm{~m})$ flat-bottomed basins. The meltwater channels have a V-shaped cross-sectional profile, cut into bedrock, and vary in depth (15-60 m), width (80-200 m), and length (200-2000 m). Some of these long, straight channels may be preferentially eroding joints and faults, similar to other areas along the AP shelf (Domack et al., 2006). The bathymetry in outer Beascochea Bay is also rugged, but this region is characterized by an anastomosing network of meltwater channels cutting through bedrock and flowing between elongated mounts, with a few small $\left(<1 \mathrm{~km}^{2}\right.$ area), deep (50-100 m depth), flat-bottomed basins located between the mounts. Water depths in this area vary between 600 and $800 \mathrm{~m}$. The meltwater channels vary in depth $(20-50 \mathrm{~m})$, width (140$250 \mathrm{~m})$, and length $(100-3000 \mathrm{~m})$, some with a V-shaped channel cross-section profiles and others with a U-shaped, flat-bottomed profiles. The channels have abrupt initiation points but terminate, generally, into the small basins that connect to other channels. Channel orientations vary from parallel to oblique to bay axis. The elongated mounts are asymmetric, carved in bedrock, with varying length (260$5000 \mathrm{~m})$, width $(210-1000 \mathrm{~m})$, and height $(15-90 \mathrm{~m})$.

Lever Glacier cove is separated from middle Beascochea Bay by a transverse ridge (Fig. 5, D-D'). This feature has been partially surveyed but shows a wedge-shaped crosssectional profile, steep distal side and gentler proximal side. The ridge is at least $5 \mathrm{~km}$ long, up to $1.5 \mathrm{~km}$ wide, and between 70 and $180 \mathrm{~m}$ high. Another transverse ridge is located less than $1 \mathrm{~km}$ from the modern ice front of Lever Glacier. The ridge was only surveyed in the northern area of the cove but it is likely present across the bay, next to the modern glacier front. It is sinuous (about $2.5 \mathrm{~km}$ long, $20 \mathrm{~m}$ high) with a prominent knob in the middle of the cove. This knob coincides with the deepest area in the cove, enhancing it further in the bathymetry. The seafloor of this cove is covered by glacial lineations (Fig. 5, A-A'), present from the proximal to the distal transverse ridges. The lineations are semi-parallel to the axis of the cove, individual features have a symmetric cross-sectional profile, and vary in length (400-1400 m), width $(100-150 \mathrm{~m})$, and heights $(5-10 \mathrm{~m})$, as well as the distance between the ridge crests $(90-260 \mathrm{~m})$. Although water depths within the cove vary from 120 to $320 \mathrm{~m}$, the glacial lineations are present throughout the cove regardless of water depth (Fig. 5b). In the CHIRP data set, the lineations are characterized by a strong surface with no internal reflectors, which likely indicates till (Fig. 7).

Funk Glacier cove and inner Beascochea Bay are separated by a large ( $2.3 \mathrm{~km}$ long, $800-1000 \mathrm{~m}$ wide, $60-150 \mathrm{~m}$ high), wedge-shaped transverse ridge (Fig. 5, E-E'). The eastern (proximal) side of the ridge is covered by a $20 \mathrm{~m}$ high, $1.4 \mathrm{~km}$ long feature that resembles a mass wasting deposit. However, this feature could also be the result of meltwater deposition generated when the ice was grounded nearby. Higher-resolution multibeam data are needed to bet-

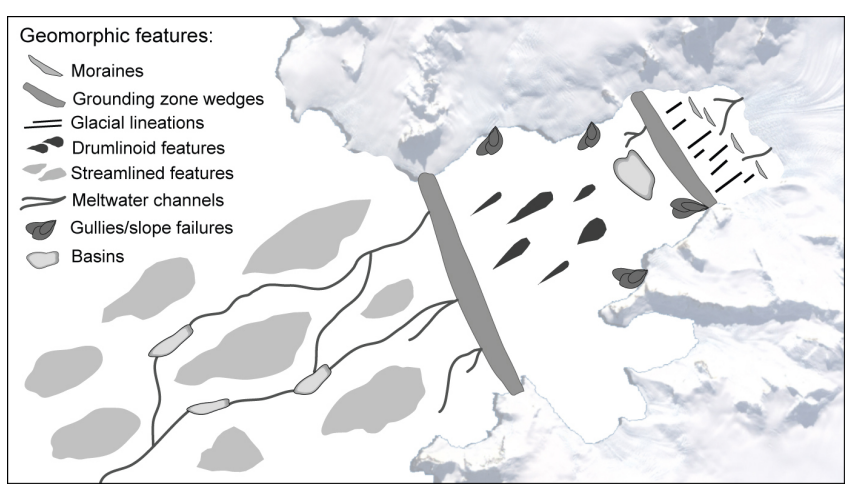

Figure 8. Schematic map view model showing the various geomorphic features found in the seafloor of glaciated bays in the western Antarctic Peninsula.

ter characterize this feature and sediment analysis to interpret its depositional origin. Several glacial lineations are present on the seafloor and can be traced from the middle of the cove to the modern front of Funk Glacier. Individual features have a symmetrical cross-sectional profile, are parallel to one another, and have varying height $(5-20 \mathrm{~m})$, width (40-100 m), and length $(160-700 \mathrm{~m})$. Unlike the lineations in Lever Glacier cove, the subsurface of these landforms resembles an amalgamation or stacked sediment packages (Fig. 7b), most likely recently reworked till. A network of meltwater channels originate near the ice front and trend towards the middle of the fjord. Channel depths vary $(6-20 \mathrm{~m})$, as do widths (30-200 m) and lengths $(70-1200 \mathrm{~m})$.

In Cadman Glacier cove we identify large promontories (up to $300 \mathrm{~m}$ high) on each side of the cove mouth, separating the cove from inner Beascochea Bay (Fig. 5c). Abundant slope failures are present on the sides of the promontories. The middle of the cove has a flat basin with water depths down to $550 \mathrm{~m}$.

\section{Discussion}

\subsection{Distribution and interpretation of seafloor features}

We have described numerous seafloor features in four bays in the western AP (additional bays are shown in the Supplement). Many of the bays show similar landform distributions and therefore we propose a schematic model representative of an assemblage of submarine landforms in bays from the western AP (Fig. 8). This spatial distribution of landforms, from the modern ice front to the outer bay area, results from combining the geomorphology of all the bays presented. The inner bay is characterized by glacial lineations, straight meltwater channels, and in some cases moraines and crevasse squeeze ridges. The inner bay and middle bay are typically separated by a transverse ridge. The middle bay is characterized by deep, flat-bottomed basins and, in some examples, drumlinoid features (drumlins and/or crag and tails), with the 


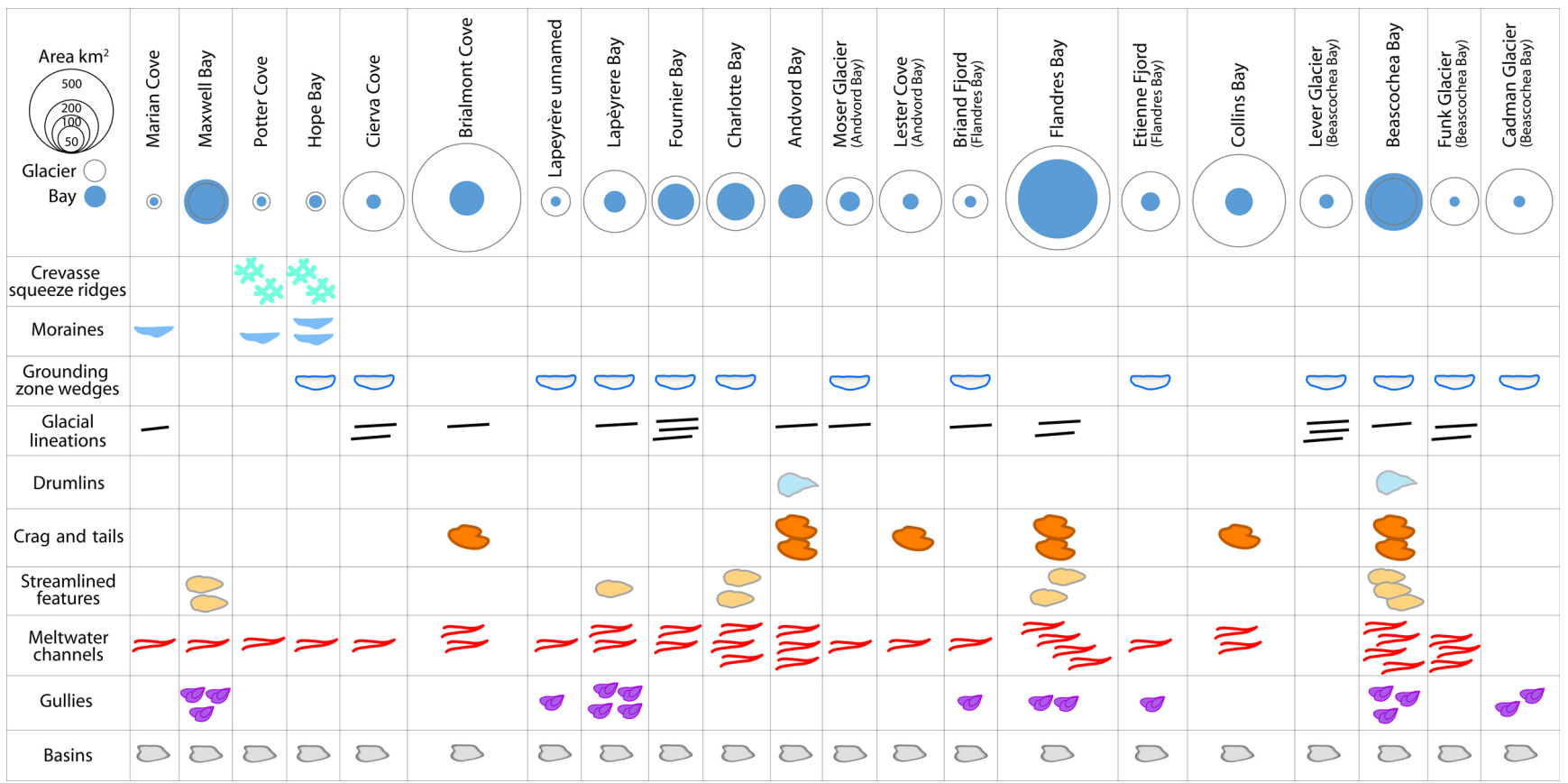

Figure 9. Comparing bay area, glacier catchment area, and submarine features found in bays. Bays are listed from northernmost (Marian Cove) to southernmost (Cadman Glacier cove). The number of symbols in the chart is a representation of the number of geomorphic features found in each bay; one symbol: 1-10 features; two symbols: 11-20 features; three symbols: 21-30 features; and four symbols: > 30 features found at that location.

stoss end pointing towards the outer bay. In most cases, the middle and outer bay are separated by another, likely larger, transverse ridge, which is immediately followed by large, asymmetrical, streamlined (elongated) features and meltwater channels in the outer bay. Although some seafloor features are common, we recognize there is some variation between the bays and within the bays themselves (Fig. 9).

Models showing geomorphic features have been presented largely for the continental shelf in Antarctica (Wellner et al., 2001; Canals et al., 2002; Evans et al., 2004; Dowdeswell et al., 2008; Graham et al., 2009), and therefore our model differs from them since we show landforms focused in the confined bay areas. Our proposed schematic model is similar to other models of landform assemblages presented for glaciated environments in Svalbard (Ottesen and Dowdeswell, 2009) and Greenland (Dowdeswell et al., 2016). However, unlike the Ottesen and Dowdeswell (2009) model for restricted areas like fjords where the seafloor is dominated by landforms transverse to ice flow, our findings in AP fjords show a combination of landforms parallel and transverse to ice flow (Fig. 8). In addition, AP fjords show evidence of subglacial meltwater flow in the form of channels carved in bedrock. Figure 9 shows the distribution of submarine landforms per bay compared to the area of the bay and the combined catchment area of the glaciers draining into each bay (also shown in Tables S1 and S2). These features were likely formed during the final ice retreat phase throughout the AP bays during the Last Glacial Maximum. However, features carved in bedrock (e.g. meltwater channels, streamlined features) are likely the result of multiple cycles of glaciation in the bays, similar to other areas on the Antarctic continental shelf (Ó Cofaigh et al., 2005; Anderson and Fretwell, 2008; Graham et al., 2009; Livingstone et al., 2013). The submarine landforms are classified into three categories based on their depositional environment and sedimentary processes forming them: (1) subglacial landforms, (2) ice-marginal landforms, and (3) recent sediment reworking throughout the bays.

\subsubsection{Subglacial landforms}

\section{Elongated, parallel ridges: glacial lineations}

Elongated ridges parallel to bay axis are interpreted as glacial lineations (Fig. 6a). In this study, lineations vary in length (between $80 \mathrm{~m}$ and $2.7 \mathrm{~km}$ long), width (between 5 and $200 \mathrm{~m}$ ), and height (between 1 and $20 \mathrm{~m}$ high). Glacial lineations typically occur in groups in the inner bay (Figs. 2b, $4 \mathrm{~b}, 5 \mathrm{~b}, \mathrm{c}$ ), while in some cases lineations are also present in the middle bay area (Fig. S1). Glacial lineations form under flowing ice over a thin deformation till layer; most glacial lineation heights in this study are less than $10 \mathrm{~m}$. The lineations are parallel to the former ice flow direction. In CHIRP, some lineations have a strong surface with no internal reflectors, 
while others are formed by stacked sediment packages of reworked sediment (Fig. 7).

\section{Teardrop-shaped ridges in sediment: drumlins}

Streamlined, teardrop-shaped ridges formed in deformable sediment are interpreted as drumlins (Fig. 6c). The stoss side indicates ice flow direction towards the bay mouth. Drumlins are covered by parallel acoustically laminated sediment (Fig. 7a). These features are observed in Beascochea Bay (Fig. 5d) and Andvord Bay (Figs. S1, S4), both very large bays (Fig. 9). In both examples, the drumlins occur in an area of ice flow convergence from two large drainage systems. This convergence may result in flow acceleration, which would explain the formation of the drumlins (Wellner et al., 2001, 2006; Larter et al., 2009).

\section{Teardrop-shaped ridges in bedrock: crag and tails}

Streamlined, teardrop ridges formed in bedrock with a sediment tail are interpreted as crag and tails (Fig. 6d). These features are present in Beascochea Bay (Fig. 5d) and Andvord Bay (Figs. S1, S4), where they are associated with drumlins and glacial lineations. Crag-and-tail features are also present in Brialmont Cove, Flandres Bay, and Collins Bay, all broad bays (Fig. 9). These features vary in length (130$900 \mathrm{~m})$, width $(40-300 \mathrm{~m})$, and height $(2-28 \mathrm{~m})$ but are in general smaller than drumlins and shorter than glacial lineations. Crag and tails are parallel to ice flow direction in the bays.

\section{Elongated, asymmetrical ridges in bedrock: streamlined features}

Large, elongated streamlined features are found in the outer bays carved in bedrock (Fig. 6b), as shown by the bowtie or hummocky reflections in the CHIRP data (Fig. 7). Actively flowing ice carved them in bedrock, most likely over multiple glaciation events (Anderson and Fretwell, 2008; Graham et al., 2009; Livingstone et al., 2013). These features are typically not symmetrical and in some areas are more elongated closer to the bay mouth and become stubbier away from the bay (Fig. 5d). Elongation at the bay mouth may indicate faster ice flow at those locations and then later deceleration as the ice reaches a larger, open area to flow outside of the confined bay (Bradwell et al., 2008).

\section{Subglacial meltwater channels}

Subglacial meltwater channels (Fig. 6d) have been carved into crystalline bedrock, in the inner bay areas (Fig. 4b) and in the outer bay areas (Fig. 5b, c). In addition, channels are more frequent in the southern bays. The meltwater channels mapped in this study area indicate a complex network of flow, with short straight and anastomosing channels. Similar meltwater channels have been mapped in other Antarc- tic regions with crystalline bedrock (Lowe and Anderson, 2002; Anderson and Fretwell, 2008; Livingstone et al., 2013; Nitsche et al., 2013) and likely also formed through multiple glaciation events. The presence of these channels highlights the production of subglacial meltwater in the northern AP region, previously only identified in southern AP areas (Dowdeswell et al., 2004; Anderson and Fretwell, 2008; Livingstone et al., 2013).

\section{Basin fill from subglacial sediment deposition}

Several meltwater channels are associated with small flatbottomed basins (Figs. 5d, 6d), similar to those found in other areas in the Antarctic continental shelf, interpreted as palaeo-subglacial lakes (Kuhn et al., 2017). Flat-bottomed basins have acoustically parallel sediment fill (Fig. 7). Subglacial sediment deposition occurs through subglacial meltwater flow and through tidal pumping, close to the grounding line (Domack, 1990; Domack et al., 2006).

\subsubsection{Ice-marginal landforms}

Large transverse ridges: grounding zone wedges (GZW)

Large, transverse sedimentary ridges, usually formed at narrow locations in the bay perimeter are interpreted as GZW (Fig. 6e). These landforms are characterized by a strong surface with no internal reflectors (Fig. 7). GZW are depositional features, formed during stillstand periods during a general ice retreat, when sediment is carried to the grounding line through bed deformation and basal melting (Alley et al., 1989; Anderson, 1999; Dowdeswell et al., 2008; Batchelor and Dowdeswell, 2015). Most of the GZW observed in the western AP bays are asymmetric, with a steep slope distal and gentler slope proximal to the ice front (Figs. 4, 5). The geometry of these transverse ridges is similar to much larger GZW in the Ross Sea (Halberstadt et al., 2016) and the Weddell Sea (Campo et al., 2017). The size of the GZW has been correlated with the length of ice stability (Alley et al., 2007; Dowdeswell and Vasquez, 2013; Batchelor and Dowdeswell, 2015), a larger GZW imply a longer period of ice stability.

\section{Small transverse ridges: moraines}

Moraines are small sedimentary ridges that can be transverse to the bay axis or arcuate, forming a lunate shape across the bay (Figs. 6g, 2, 3). These transverse ridges can form through various processes including melting out of basal and englacial debris-rich ice, ice push, dumping of supraglacial debris, and lodgement (Powell, 1981; Powell and Domack, 1995; Batchelor and Dowdeswell, 2015). The moraines are interpreted to form during ice retreat, but unlike the GZW the duration of the stillstand is much shorter and possibly more frequent (Ottesen et al., 2005; Batchelor and Dowdeswell, 2015). 


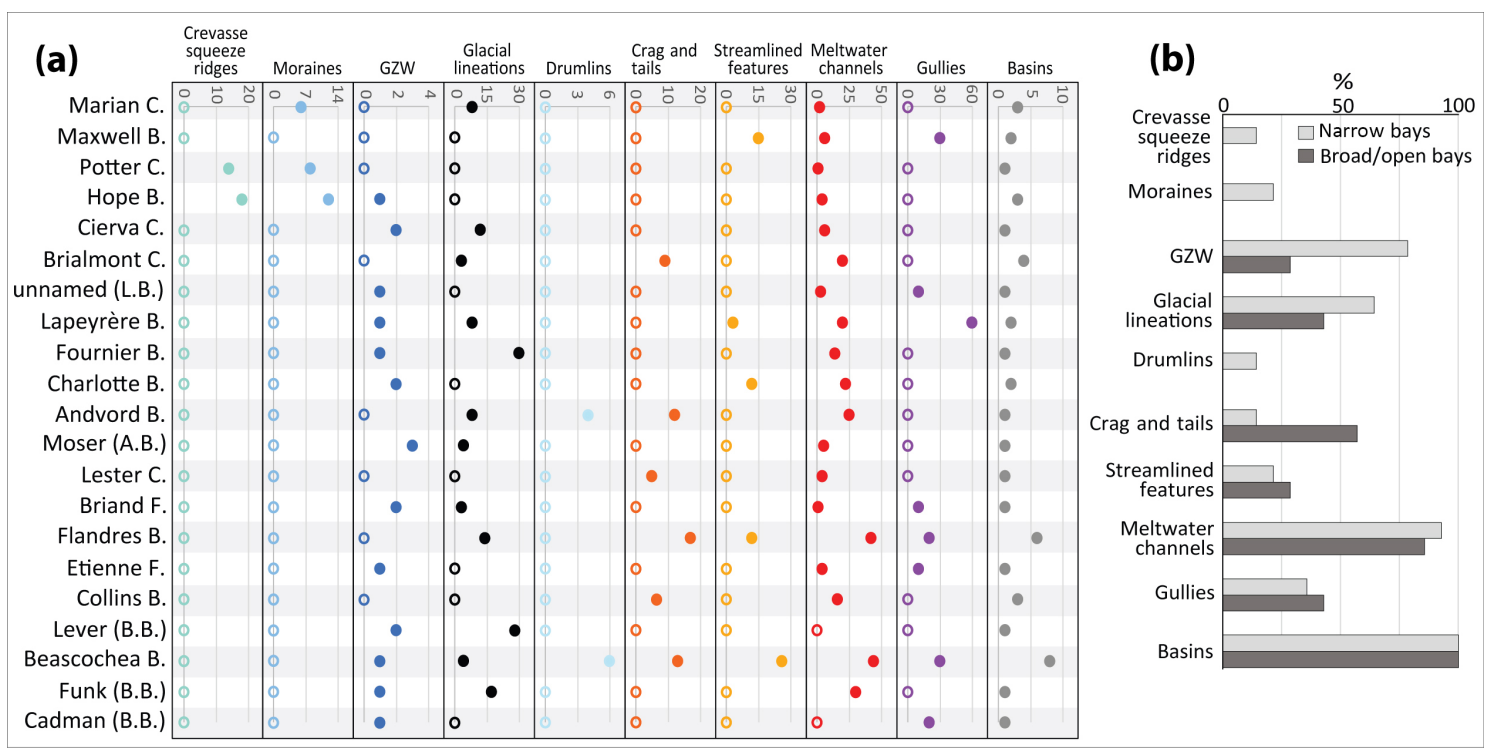

Figure 10. (a) Number of features found in the bays; open circles represent zero. The bays are listed from northernmost to southernmost latitude; C. is cove, B. is bay, F. is fjord, L.B. is Lapeyrère Bay, A.B. is Andvord Bay, and B.B. is Beascochea Bay. (b) Percent of narrow (light grey) and broad and open bays (dark grey) in which the listed geomorphic features are found.

\section{Small ridges in networks: crevasse squeeze ridges}

Small ridges, cross-cutting each other, forming a network are interpreted as crevasse squeeze ridges (Figs. $6 \mathrm{~g}$ ). These only occur in two bays (Figs. 2, 3), in proximal settings with shallow water depths $(<120 \mathrm{~m})$. Crevasse squeeze ridges are not a common feature in Antarctica, but they have been observed in the Amundsen Sea embayment (Klages et al., 2013). These landforms have been reported in Iceland (Bennett and Glasser, 2009) and Svalbard (Ottesen and Dowdeswell, 2006, 2009) occurring either as symmetrical, low ridges or as rhombohedral ridges, about $5 \mathrm{~m}$ high, found on the ice proximal margin of moraines. These ridges form by squeezing till in crevasses formed at the base of grounded ice, and they indicate ice stagnation followed by a rapid uncoupling from the seafloor (Powell and Domack, 1995; Ottesen and Dowdeswell, 2006; Bennett and Glasser, 2009). The preservation of these features indicates that no further ice front readvance has occurred over them.

\subsubsection{Recent sediment reworking throughout the bays}

\section{Slope failures: mass wasting and gullies}

Slope failures occur in transverse ridges (either moraines or GZW) that result in the formation of a large fan-shaped feature in the bays (Figs. 2, 5). These features are not common in these bays but they are observed in the inner bay areas. Lobes are between 200 and $1200 \mathrm{~m}$ long and between 300 and $500 \mathrm{~m}$ wide. The characteristic steep walls of the glacial valleys have gullies (Fig. 6f) throughout the perimeter of the bays, although in some bays gullies are more abundant than in others (Figs. 9, 10).

\section{Proglacial meltwater channels}

Straight, long, wide channels, carved in soft sediment, are interpreted as a modern erosional feature (Fig. 4b). These channels are differentiated from the subglacial meltwater channels by their linear channel axis. Although some are slightly sinuous, they do not form complex flow networks; some are observed in low numbers or even isolated in a bay (Fig. 4b). These types of channels are common in Chilean bays (Dowdeswell and Vasquez, 2013) and northern hemispheric fjords (Syvitski et al., 1987; Bennett and Glasser, 2009), where they form by dense sediment flows or turbidity currents resulting from glaciofluvial meltwater or slope failures (Syvitsky et al., 1987; Dowdeswell and Vasquez, 2013).

\section{Basin fill from turbid meltwater and rainout}

The proglacial channels carry sediment flows from bathymetric high regions to deep basins (Fig. 6b, d, f), where sediment of varying sizes is deposited in layers, forming the acoustically laminated basin fill (Fig. 7). In addition, hemipelagic processes (Powell and Domack, 1995; Ó Cofaigh and Dowdeswell, 2001; Domack et al., 2006) and meltwater plumes originating at the glacier terminus (Domack et al., 1994, 2006) contribute to sediment deposition in basins. Sediment reworking processes have likely been occurring since grounded ice started retreating; however, the recent warming period in the AP area may have contributed to an 

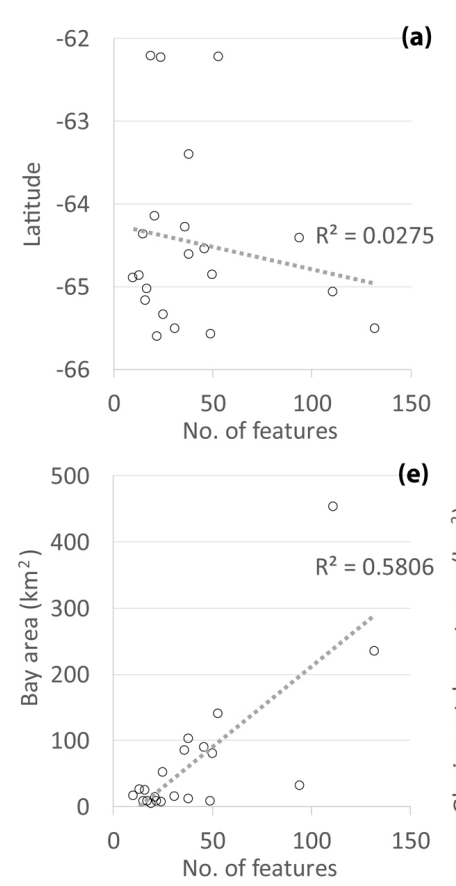
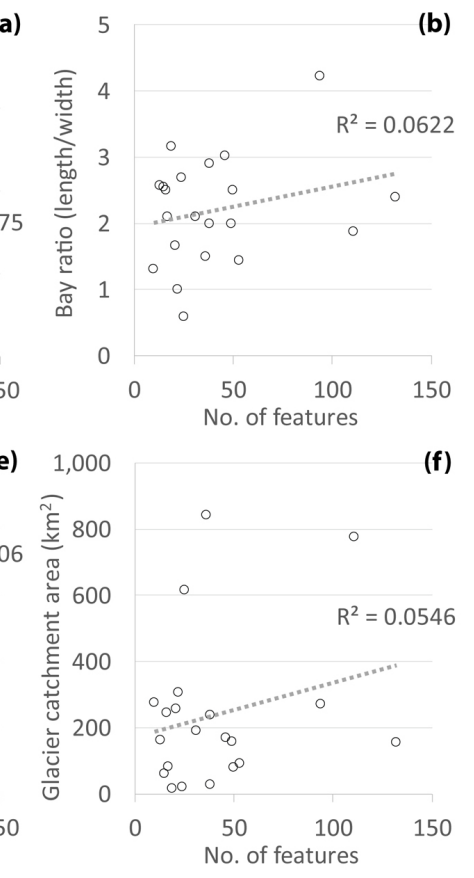
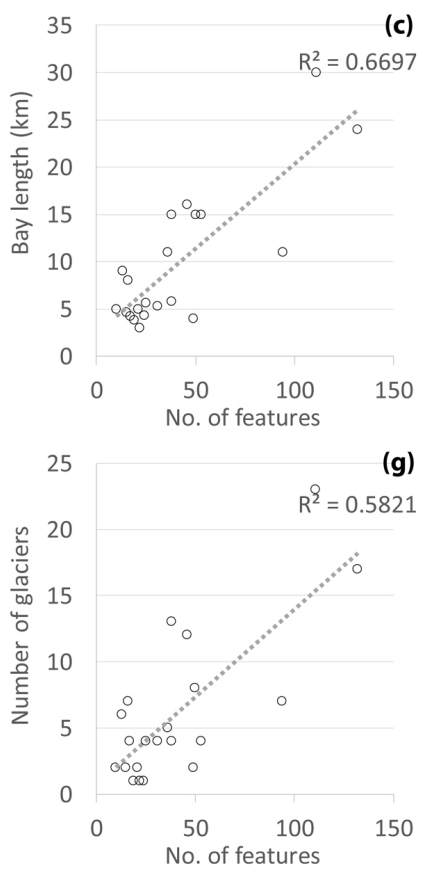

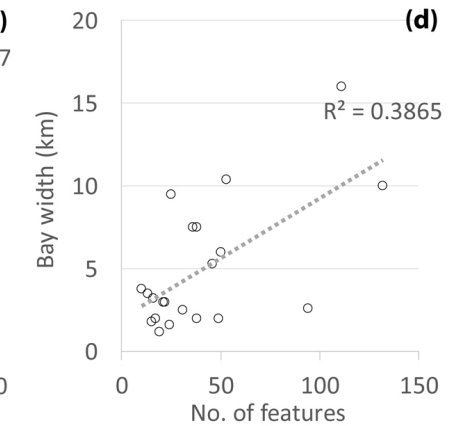

(d)

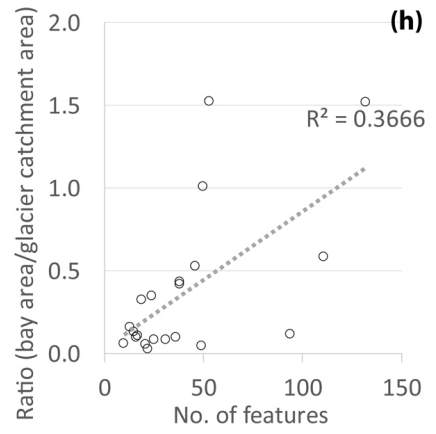

Figure 11. Graphs showing number of overall features found in the study areas as they relate to latitude, bay ratio, bay length, bay width, bay area, glacier catchment area, number of glaciers, and the ratio of bay area to glacier catchment area.

increase in meltwater production, which may have resulted in larger sediment reworking.

\subsection{Observations on ice flow dynamics}

There is a variable spatial distribution of the submarine landforms presented in this study (Fig. 1). Although we present a generic model representative of the geomorphology in the western AP bays (Fig. 8), it is clear that not all the features are present in all the bays and therefore we examined the local conditions in order to understand ice flow in the western AP.

\subsubsection{Latitude and temperature gradient}

Although there are some latitudinal differences between the bays observed, Marian Cove $\left(62^{\circ} 12^{\prime} \mathrm{S}\right)$ in the north and Cadman Glacier cove $\left(65^{\circ} 36^{\prime} \mathrm{S}\right)$ in the south, we did not find a direct correlation between latitude and the number of features found in the bays (Fig. 11a). However, the number of glacial lineations and meltwater channels increased towards the southern AP (Figs. 9 and 10). In addition, the complexity of the meltwater channel flow networks increased towards the south AP.

In northern locations in our study area, the seafloor has a lower relief, e.g. Maxwell Bay (Fig. 2) and Hope Bay (Fig. 3). Although there are some bathymetric highs, the seafloor appears smoother overall. In comparison, the southern bays have a more rugged seafloor, with very high differences in relief, e.g. Flandres Bay (Fig. S6) and Beascochea
Bay (Fig. 5). The deep basins with flat bottoms in Flandres Bay and Beascochea Bay contrast with the variable relief around them. We attribute these differences in seafloor roughness to a higher sediment cover in the northern areas compared to the southern areas. The increased sediment cover is related to higher sediment accumulation rates, documented in Maxwell Bay by Milliken et al. (2009) and Boldt et al. (2013). Thus the smooth seafloor is likely due to burial of glacial features. The smooth seafloor cover in Maxwell Bay has more resemblance with Chilean fjords (e.g. Dowdeswell and Vasquez, 2013) and bays in South Georgia (e.g. Hodgson et al., 2014) than it does with other AP bays.

\subsubsection{Bay area and glacier drainage area}

One of the apparent variables in this comparison is the size of the bay area and the catchment area of the glaciers draining into any particular bay (Fig. 9). A reasonable assumption is that a larger drainage area would likely result in larger amounts of sediment and meltwater delivered to the seafloor, which could potentially form more seafloor features as ice flows in the bay. We compared bay area and glacier catchment area (total combined area of the glaciers draining into each bay) to the number of features mapped in the bays. We found a relatively high correlation between the bay area and the number of features (Fig. 11e) and a very poor correlation with total glacier catchment area (Fig. 11f). Larger bays have, on average, more submarine landforms, but a larger drainage area does not result in more submarine landforms in the bay. 
This conclusion implies that landform formation is complex and not directly dependent on the amount of ice flow into the bays.

When comparing glacier catchment areas to the type of features found (Fig. 9), the smaller drainage areas are correlated with the smaller size features, e.g. moraines, which are not found in bays with larger catchment drainage areas. This suggests that smaller fluctuations in the ice flow (that would result in the formation of smaller landforms) would not be apparent in larger glacial systems. Therefore, we conclude that the size of the bays, and not the size of the catchment area, dictates the number of features that form in the seafloor, but smaller glacier catchment areas are able to preserve evidence of small fluctuations in ice flow. This conclusion is consistent with results from Bourgeois Fjord and Blind Bay (Garcia et al., 2016), near Marguerite Bay in the southern $\mathrm{AP}$, where an inverse relation between drainage basin size and retreat of the glacier terminus was found. Similarly, Fox and Cooper (1998) measured the largest size reduction on the smaller ice bodies in the AP.

\subsubsection{Geometry of bays}

Since there is a large degree of variability regarding size of the bays (Fig. 9), we additionally analysed the bay length, bay width, and bay ratio (length / width). Bays with ratios lower than 1 were classified as open bays, ratios between 1 and 2 were classified as broad bays, and ratios higher than 2 were classified as narrow bays. We refer to this classification as the geometry of the bays. This geometry was compared to the type (and number) of features found in each observed bay (Fig. 10b). Because most bays in our study area were classified as narrow, we use "percentage of bays" as a way to normalize the results. Therefore, we refer to the percentage of narrow (or combined broad and open) bays where certain feature was identified; for example, Fig. 10b shows that $78 \%$ of the narrow bays have GZW, while only $28 \%$ of the broad and open bays have this same type of feature.

In Fig. 10b we note that crevasse squeeze ridges, moraines and drumlins occur only in narrow bays; GZW and glacial lineations occur mostly in narrow bays; crag and tails occur mostly in broad and open bays; and streamlined features, gullies and slope failures, meltwater channels, and basins tend to occur in all bays regardless of the bay geometry. In addition, we compared bay length, bay width, and bay ratio to the number of features mapped (Fig. 11b-d). We see that both bay length and width have a high correlation with the number of features found in the bay.

From these observations, we conclude that the geometry of the bay dictates the types of features that form. Narrower bays tend to form transverse features, like moraines and GZW, which form during periods of ice stabilization (Anderson, 1999; Alley et al., 2007; Dowdeswell et al., 2008; Dowdeswell and Vasquez, 2013; Batchelor and Dowdeswell, 2015). The width of the glacial valley has been suggested to play an important role for glacial flow (O'Neel et al., 2005; Joughin et al., 2008; Robel, 2017). Similarly, widths of icestream troughs, along with water depth, control ice flow by increasing the lateral resistance (Whillans and van deer Veen, 1997; Jamieson et al., 2012). Lateral drag increases as the width narrows, which may lead to ice stabilization that could result in transverse features, based on the amount of sediment flux and duration of the stillstand (Howat and Domack, 2003; Dowdeswell and Vasquez, 2013). Transverse-to-flow features in the Ross Sea and Weddell Sea (Halberstadt et al., 2016; Campo et al., 2017) are larger than the GZW and moraines identified in this study and are the result of a much larger ice flow system. Therefore, width may play a major role in confined flow, e.g. fjords and bays.

\subsection{Comparison to other glaciated regions}

Similar assemblages of submarine landforms are found in bays of Greenland (Dowdeswell et al., 2016) and, to a lesser extent, in Svalbard (Ottesen and Dowdeswell, 2009). In Greenland, Dowdeswell et al. (2016) observed lineations near the modern ice front followed by a Little Ice Age (LIA) moraine with channels flowing towards a deep basin in the middle of the fjord, and streamlined features in the outer fjord areas. In Svalbard, several transverse retreat moraines and a larger LIA moraine ridge characterize the inner bay, followed by drumlinoid features in the middle to outer bay and larger transverse ridges in the outer fjord (Ottesen and Dowdeswell, 2009). Because Svalbard experiences higher sedimentation rates, compared to the AP, it is possible that some of the features seemingly not present may actually be covered.

Bays in South Georgia, an island northeast of the AP, also show some similarities to west AP bays; a shallower inner bay, followed by a moraine and a deep basin towards the outer bay (Hodgson et al., 2014). However, many of the bays in South Georgia have smooth seafloors, which indicates any other older features (if any) are likely buried. Dowdeswell and Vasquez (2013) mapped the geomorphology of some bays near the Southern Patagonian Ice Cap in Chile, and they show less similarities to western AP bays in general. Bays in Chile are dominated by meltwater production that is reworking and redistributing the sediment, draping the seafloor, creating a smooth cover throughout (Dowdeswell and Vasquez, 2013). Much less meltwater production and sediment reworking, along with relatively less sediment cover in the western AP bays, has enabled us to map submarine landforms in detail.

\subsection{Possible late Holocene glacial advance}

The seafloor in the ice proximal area in several of the bays presented in this study is characterized by a proximal transverse ridge, in most cases with glacial lineations, located a few kilometres from the modern ice front; Marian Cove 


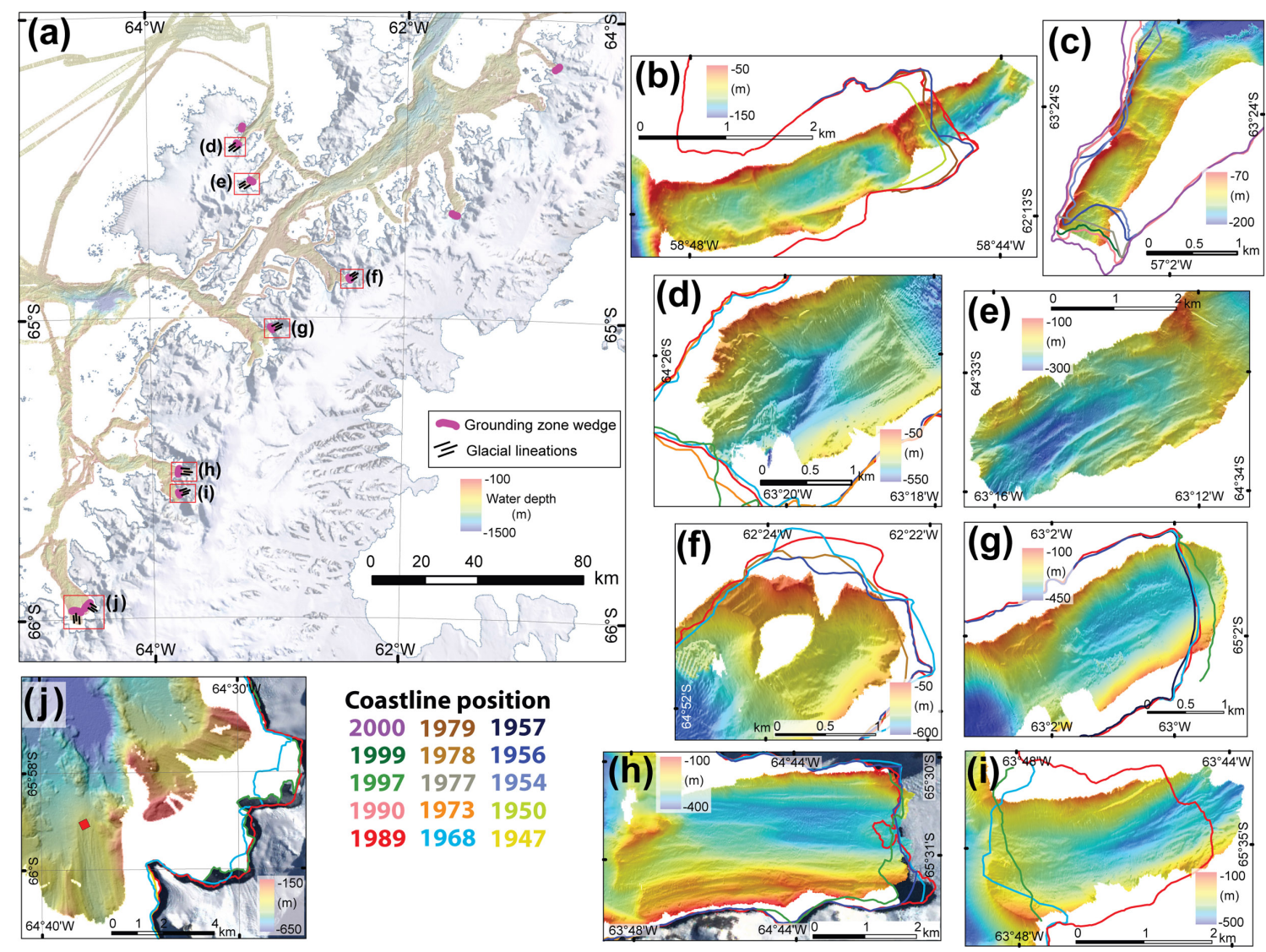

Figure 12. Map of the northwestern side of the Antarctic Peninsula (a) and features in the inner bays (b-j). (b) Marian Cove and (c) Hope Bay are not in map (a); for location refer to Fig. 1. Barilari Bay (j) from Christ et al. (2014) shows the proximal grounding zone wedge and glacial lineations; the red square shows the location of sediment core collected in 2010 and used for chronology in Christ et al. (2014). Coastline positions from Cook et al. (2014).

(Fig. 12b), Hope Bay (Fig. 12c), Lapeyrère Bay (Fig. 12d), Fournier Bay (Fig. 12e), Moser Glacier cove (Fig. 12f), Briand Fjord (Fig. 12g), Lever Glacier cove (Fig. 12h), and Funk Glacier cove (Fig. 12i) show these features. We propose these proximal features are associated with a LIA glacial advance. Similar sets of features (an ice proximal transverse ridge followed by either smaller transverse ridges or elongated ridges parallel to the modern ice front) in the inner bays have also been observed in Chile (Dowdeswell and Vasquez, 2013), Greenland (Dowdeswell et al., 2016), and Svalbard (Ottesen et al., 2005; Ottesen and Dowdeswell, 2009) and have been interpreted as LIA landforms. In Antarctica, there has been less published research associating geomorphology and the LIA. Christ et al. (2014) observed these same set of features in the ice proximal region of Barilari Bay (Fig. 12j) and referred to them as a "fluted grounding zone wedge". They suggest a cooling and glacial advance between AD 1220 and AD 1868 (Christ et al., 2014) based on sedimentological analysis and ${ }^{210} \mathrm{~Pb}$ and radiocarbon dates. Garcia et al. (2016) describe the geomorphology of a western AP fjord near Marguerite Bay, south of our study area. They show transverse, crescent-shaped, and longitudinal ridges ("morainic" landforms), along with elongated ridges, semiparallel to the fjord length in the inner bay. Although they do not present any sedimentological analysis or dating, they interpret these inner features as a result of LIA glacial advance in this fjord because these submarine landforms appear pristine, with no evidence of a subsequent glacier advance, relatively recent, and are located only a few kilometres from the modern ice front. In Potter Cove (Fig. 2c), transverse moraines in the inner cove are likely associated with LIA advance (Wölfl et al., 2016), but no dating was conducted on those features. In the neighbouring Maxwell Bay (Fig. 2), no sedimentological evidence was found of LIA advance (Milliken et al., 2009), which may indicate that if there was any LIA advance in the western AP bays, only smaller systems (narrow bays) and/or shallow bays would record and preserve any geomorphic evidence, as suggested by our observations above. The LIA event has been reported in western AP bays and the South Shetland Island by several authors (Domack et al., 1995, 2001, 2003; Shevenell et al., 1996; Hall, 2007; Hass et al., 2010; Monien et al., 2011; Simms et al., 2012) but 
it may be a more widespread event throughout the AP than previously assumed. However, it is worth noting that LIA interpretations by those authors were based on sedimentological or terrestrial analysis that included results from dating techniques. Our interpretations are based only on geomorphology and therefore chronology assessments are necessary to support this argument. Another possibility is that some of these features are younger than LIA. Cook et al. (2014) mapped the glacier front of several bays in the AP and some of the glacier front lines coincide with the location of transverse landforms (Fig. 12c, g, h) in small bays. To our knowledge, no sediment samples have been collected from any of these proximal locations and thus no chronometric data have been completed to verify the ages of these transverse features.

\section{Summary and conclusions}

We present multibeam swath bathymetry from bays in the South Shetland Islands and the western Antarctic Peninsula. The subglacial landforms were classified into three categories based on their depositional environment and sedimentary processes forming them: subglacial, ice-marginal, and recent sediment reworking. We propose a schematic model showing geomorphic features present in western AP bays; from glacial lineations and moraines in the inner bay to grounding zone wedges and drumlinoid features in the middle bay and streamlined features and meltwater channels in the outer bay areas.

We analysed the local variables of each bay including latitude, bay area, bay length, bay width, glacier catchment area, and the seafloor lithology to understand controls on ice flow behaviour. Specific results include the following. (1) Bay length and width exert a control on the number of landform features found in the bays; in addition, the geometry of the bays dictates the types of features that will form. Narrower bays tend to form transverse-to-flow features because the lateral drag of the ice flow increases as the valley width narrows which may lead to ice flow stabilization. (2) Small size features, e.g. moraines, were only found in narrow bays with smaller drainage areas and not in larger-sized drainages areas, suggesting that short-lived environmental fluctuations, responsible for the formation of these features, would only be recorded by the smaller glacial systems. (3) Two different types of meltwater channels were identified: straight, wide channels carved in soft sediment are a modern erosional feature, while the complex network of channels carved in bedrock are subglacial, which highlights the presence of subglacial meltwater production in the northern AP region, possibly through several glacial cycles.

Finally, based on analogous assemblages of landforms reported in other locations, we propose the geomorphic features found in the seafloor of some of the proximal bay areas were formed during the LIA glacial advance. If this is the case, then glacier systems in the AP have a greater sensitivity to minor atmospheric and oceanic fluctuations than previously suggested. Future research should include additional multibeam coverage as well as sedimentological analysis and chronometric constraints in order to confirm LIA in these bays and in other areas of the Antarctic Peninsula.

Data availability. The multibeam and CHIRP data set collected by the RV/IB Nathaniel B. Palmer (NBP) can be accessed through the Lamont-Doherty Earth Observatory at www.marine-geo.org. The data set collected by the RV/IB Araon (ARA) was used with the permission of Kyu-Cheul Yoo from the Korea Polar Research Institute.

\section{The Supplement related to this article is available online} at https://doi.org/10.5194/tc-12-205-2018-supplement.

Competing interests. The authors declare that they have no conflict of interest.

Acknowledgements. This research was funded by the National Science Foundation, Office of Polar Programs grant no. OPP0739596. YPM was supported by a National Science Foundation Graduate Research Fellowship. We thank the crew and science parties of the RV/IB Nathaniel B. Palmer and Araon cruises to the Antarctic Peninsula. Data included in this study were collected during cruises NBP0201, NBP0502, NBP0602A, NBP0703, NBP1001, NBP1203, and ARA1304. NBP1001 and NBP1203 as part of the LARISSA program. We specially thank Kyu-Cheul Yoo for data from ARA1304. We would also like to thank Alastair G. C. Graham and Stephen Livingstone for their insightful reviews and comments which greatly improved our manuscript.

Edited by: Chris R. Stokes

Reviewed by: Alastair G. C. Graham and Stephen Livingstone

\section{References}

Alley, R. B., Blankenship, D. D., Rooney, S. T., and Bentley, C. R.: Sedimentation beneath ice shelves - The view from ice stream B, Mar. Geol., 85, 101-120, 1989.

Alley, R. B., Anandakrishnan, S., Dupont, T. K., Parizek, B. R., and Pollard, D.: Effect of sedimentation on icesheet grounding-line stability, Science, 315, 1838-1841, https://doi.org/10.1126/science.1138396, 2007.

Anderson, J. B.: Antarctic Marine Geology, Cambridge University Press, New York, 1999.

Anderson, J. B. and Fretwell, L. O.: Geomorphology of the onset area of a paleo-ice stream, Marguerite Bay, Antarctic Peninsula, Earth Surf. Proc. Land., 33, 503-512, 2008. 
Anderson, J. B., Wellner, J. S., Lowe, A. L., Mosola, A. B., and Shipp, S. S.: Footprint of the expanded West Antarctic Ice Sheet: ice stream history and behavior, GSA Today 11, 4-9, 2001.

Arndt, J. E., Schenke, H. W., Jakobsson, M., Nitsche, F. O., Buys, G., Goleby, B., Rebesco, M., Bohoyo, F., Hong, J., Black, J., Greku, R., Udintsev, G., Barrios, F., Reynoso-Peralta, W., Taisei, M., and Wigley, R.: The International Bathymetric Chart of the Southern Ocean (IBCSO) Version 1.0 - A new bathymetric compilation covering circumAntarctic waters, Geophys. Res. Lett., 40, 3111-3117, 2013.

Ashley, G. M. and Smith, N. D.: Marine sedimentation at a calving glacier margin, Geol. Soc. Am. Bull., 112, 657-667, 2000.

Batchelor, C. L. and Dowdeswell, J. A.: Ice-sheet grounding zone wedges (GZWs) on high-latitude continental margins, Mar. Geol., 363, 65-92, https://doi.org/10.1016/j.margeo.2015.02.001, 2015.

Bennett, M. and Glasser, N.: Glacial Geology: ice sheets and landforms, Wiley-Blackwell, UK, 2009.

Boldt, K. V., Nittrouer, C. A., Hallet, B., Koppes, M. N., Forrest, B. K., Wellner, J. S., and Anderson, J. B.: Modern rates of glacial sediment accumulation along a $15^{\circ} \mathrm{S}-\mathrm{N}$ transect in fjords from the Antarctic Peninsula to southern Chile, J. Geophys. Res.Earth, 118, 2072-2088, 2013.

Bradwell, T., Stoker, M., and Krabbendam, M.: Megagrooves and streamlined bedrock in NW Scotland: the role of ice streams in landscape evolution, Geomorphology, 97, 135-156, 2008.

Campo, J. M., Wellner, J. S., Domack, E., Lavoie, C., and Yoo, K. C.: Glacial geomorphology of the northwestern Weddell Sea, eastern Antarctic Peninsula continental shelf: Shifting ice flow patterns during deglaciation, Geomorphology, 280, 89-107, 2017.

Canals, M., Urgeles, R., and Calafat, A. M.: Deep sea-floor evidence of past ice streams off the Antarctic Peninsula, Geology, 28, 3134, 2000.

Canals, M., Casamor, J. L., Urgeles, R., Calafat, A. M., Domack, E. W., Baraza, J., Farran, M., and De Batist, M.: Seafloor evidence of a subglacial sedimentary system off the northern Antarctic Peninsula, Geology, 30, 603-606, 2002.

Christ, A.J., Talaia-Murray, M., Elking, N., Domack, E.W., Leventer, A., Lavoie, C., Brachfeld, S., Yoo, K., Gilbert, R., Jeong, S., Petrushak, S., Wellner, J., and the LARISSA group: Late Holocene glacial advance and ice shelf growth in Barilari Bay, Graham Land, west Antarctic Peninsula, Geol. Soc. Am. Bull., 127, 297-315, https://doi.org/10.1130/B31035.1, 2014.

Cook, A. J. and Vaughan, D. G.: Overview of areal changes of the ice shelves on the Antarctic Peninsula over the past 50 years, The Cryosphere, 4, 77-98, https://doi.org/10.5194/tc-4-77-2010, 2010.

Cook, A. J., Vaughan, D. G., Luckman, A. J., and Murray, T.: A new Antarctic Peninsula glacier basin inventory and observed area changes since the 1940s, Antarct. Sci., 26, 614-624, 2014.

Domack, E., Amblas, D., Gilbert, R., Brachfeld, S., Camerlenghi, A., Rebesco, M., Canals, M., and Urgeles, R.: Subglacial morphology and glacial evolution of the Palmer deep outlet system, Antarctic Peninsula, Geomorphology, 75, 125-142, 2006.

Domack, E. W.: Laminated terrigenous sediments from the Antarctic Peninsula: the role of subglacial and marine processes, Geological Society, London, Special Publications, 53, 91-103, https://doi.org/10.1144/GSL.SP.1990.053.01.05, 1990.
Domack, E. W. and Ishman, S.: Oceanographic and physiographic controls on modern sedimentation within Antarctic fjords, Geol. Soc. Am. Bull., 105, 1175-1189, 1993.

Domack, E. W., Foss, D. J. P., Syvitski, J. P. M., and McClennen, C. E.: Transport of suspended particulate matter in an Antarctic fjord, Mar. Geol., 121, 161-170, 1994.

Domack, E. W., Ishman, S. E., Stein, A. B., McClennen, C. E., and Jull, A. J. T.: Late Holocene advance of the Muller Ice Shelf, Antarctic Peninsula: sedimentological, geochemical, and palaeontological evidence, Antarct. Sci., 7, 159-170, 1995.

Domack, E. W., Leventer, A., Dunbar, R., Taylor, F., Brachfeld, S., and Sjuunneskog, C.: Chronology of the Palmer Deep site, Antarctic Peninsula: a Holocene palaeoenvironmental reference for the circum-Antarctic, The Holocene, 11, 1-9, https://doi.org/10.1191/095968301673881493, 2001.

Domack, E. W., Leventer, A., Root, S., Ring, J., Williams, E., Carlson, D., Hirshorn, E., Wright, W., Gilbert, R., and Burr, G.: Marine sedimentary record of natural environmental variability and recent warming in the Antarctic Peninsula, in: Antarctic Peninsula Climate Variability: Historical and Paleoenvironmental Perspectives, Antarctic Research Series, edited by: Domack, E., Levente, A., Burnet, A., Bindschadler, R., Convey, P., and Kirby, M., 79, 205-224, https://doi.org/10.1029/AR079p0205, 2003.

Dowdeswell, J. A. and Vasquez, M.: Submarine landforms in the fjords of southern Chile: implications for glacimarine processes and sedimentation in a mild glacierinfluenced environment, Quaternary Sci. Rev., 64, 1-19, https://doi.org/10.1016/j.quascirev.2012.12.003, 2013.

Dowdeswell, J. A., ÓCofaigh, C., and Pudsey, C. J.: Continental slope morphology and sedimentary processes at the mouth of an Antarctic palaeo-ice stream, Mar. Geol., 204, 203-214, 2004.

Dowdeswell, J. A., Ottesen, D., Evans, J., OCofaigh, C., and Anderson, J. B.: Submarine glacial landforms and rates of ice-stream collapse, Geology, 36, 819-822, https://doi.org/10.1130/G24808A, 2008.

Dowdeswell, J. A., Hogan, K. A., Evans, J., Noormets, R., Ó Cofaigh, C., and Ottesen, D.: Past-ice sheet flow east of Svalbard inferred from streamlined subglacial landforms, Geology, 38, 163166, https://doi.org/10.1130/G30621.1, 2010.

Dowdeswell, J. A., Hogan, K. A., and Ó Cofaigh, C.: Submarine glacial-landform distribution across the West Greenland margin: a fjord-shelf-slope transect through the Uummannaq system $\left(70^{\circ}\right.$ to $\left.71^{\circ} \mathrm{N}\right)$, in: Atlas of Submarine Glacial Landforms: Modern, Quaternary and Ancient, edited by: Dowdeswell, J. A., Canals, M., Jakobsson, M., Todd, B. J., Dowdeswell, E. K., and Hogan, K. A., Geological Society, London, Memoirs, 46, 453460, https://doi.org/10.1144/M46.150, 2016.

Evans, J., Dowdeswell, J. A., and ÓCofaigh, C.: Late Quaternary submarine bedforms and ice-sheet flow in Gerlache Strait and on the adjacent continental shelf, Antarctic Peninsula, J. Quaternary Sci., 19, 397-407, https://doi.org/10.1002/jqs.831, 2004.

Fernandez, R. A., Anderson, J. B., Wellner, J. S., Minzoni, R. L., Halet, B., and Smith, R. T.: Latitudinal variation in glacial erosion rates from Patagonia and the Antarctic Peninsula $\left(46^{\circ} \mathrm{S}-65^{\circ} \mathrm{S}\right)$, Geol. Soc. Am. Bull., 128, 1000-1023, https://doi.org/10.1130/B31321.1, 2016.

Fox, A. J. and Cooper A. P. R.: Climate-change indicators from archival aerial photography of the Antarctic Peninsula, Annals of Glaciology, 27, 636-642, 1998. 
Fretwell, P., Pritchard, H. D., Vaughan, D. G., Bamber, J. L., Barrand, N. E., Bell, R., Bianchi, C., Bingham, R. G., Blankenship, D. D., Casassa, G., Catania, G., Callens, D., Conway, H., Cook, A. J., Corr, H. F. J., Damaske, D., Damm, V., Ferraccioli, F., Forsberg, R., Fujita, S., Gim, Y., Gogineni, P., Griggs, J. A., Hindmarsh, R. C. A., Holmlund, P., Holt, J. W., Jacobel, R. W., Jenkins, A., Jokat, W., Jordan, T., King, E. C., Kohler, J., Krabill, W., Riger-Kusk, M., Langley, K. A., Leitchenkov, G., Leuschen, C., Luyendyk, B. P., Matsuoka, K., Mouginot, J., Nitsche, F. O., Nogi, Y., Nost, O. A., Popov, S. V., Rignot, E., Rippin, D. M., Rivera, A., Roberts, J., Ross, N., Siegert, M. J., Smith, A. M., Steinhage, D., Studinger, M., Sun, B., Tinto, B. K., Welch, B. C., Wilson, D., Young, D. A., Xiangbin, C., and Zirizzotti, A.: Bedmap2: improved ice bed, surface and thickness datasets for Antarctica, The Cryosphere, 7, 375-393, https://doi.org/10.5194/tc-7-375-2013, 2013.

Gales, J. A., Larter, R. D., Mitchell, N. C., and Dowdeswell, J. A.: Geomorphic signature of Antarctic submarine gullies: implications for continental slope processes, Mar. Geol., 337, 112-124, https://doi.org/10.1016/j.margeo.2013.02.003, 2013.

Garcia, M., Dowdeswell, J. A., Noormets, R., Hogan, K. A., Evans, J., ÓCofaigh, C., and Larter, R. D.: Geomorphology and shallow-acoustic investigation of an Antarctic Peninsula fjord system using high resolution ROV and shipboard geophysical observations: ice dynamics and behaviour since the Last Glacial Maximum, Quaternary Sci. Rev., 153, 122-138, https://doi.org/10.1016/j.quascirev.2016.10.014, 2016.

Graham, A. G. C. and Smith, J. A.: Palaeoglaciology of the Alexander Island ice cap, western Antarctic Peninsula, reconstructed from marine geophysical and core data, Quaternary Sci. Rev., 35, 63-81, 2012.

Graham, A. G. C., Larter, R. D., Gohl, K., Hillenbrand, C. D., Smith, J. A., and Kuhn, G.: Bedform signature of a West Antarctic palaeo-ice stream revels a multi-temporal record of flow and substrate control, Quaternary Sci. Rev., 28, 2774-2793, 2009.

Graham, A. G. C., Kuhn, G., Meisel, O., Hillenbrand, C. D., Hodgson, D. A., Ehrmann, W., Wacker, P., Wintersteller, P., Ferreira, C. D. S., Romer, M., White, D., and Bohrmann, G.: Major advance of South Georgia glaciers during the Antarctic Cold Reversal following extensive sub-Antarctic glaciation, Nat. Commun., 8, 14798, https://doi.org/10.1038/ncomms14798, 2017.

Griffith, T. W. and Anderson, J. B.: Climatic control of sedimentation in bays and fjords of the northern Antarctic Peninsula, Mar. Geol., 181-204, 1989.

Halberstadt, A. R. W., Simkins, L. M., Greenwood, S. L., and Anderson, J. B.: Past ice-sheet behaviour: retreat scenarios and changing controls in the Ross Sea, Antarctica, The Cryosphere, 10, 1003-1020, https://doi.org/10.5194/tc-10-1003-2016, 2016.

Hall, B. L.: Late-Holocene advance of the Collins Ice Cap, King George Island, South Shetland Islands, The Holocene, 17, 12531258, 2007.

Hass, H. C., Kuhn, G., Monien, P., Brumsack, H. J., and Forwick, M.: Climate fluctuations during the past two millennia as recorded in sediments from Maxwell Bay, South Shetland Islands, West Antarctica, in: Fjord systems and archives, edited by: Howe, J. A., Austin, W. E. N., Forwick, M., and Paetsel, M., Geological Society, London, Special Publications, 344, 243-260, https://doi.org/10.1144/SP344.17, 2010.
Heroy, D. C. and Anderson, J. B.: Ice-sheet extent of the Antarctic Peninsula region during the Last Glacial Maximum (LGM) Insights from glacial geomorphology, Geol. Soc. Am Bull., 117, 1497-1512, 2005.

Hodgson, D. A., Graham, A. G. C., Griffiths, H. J., Roberts, S. J., Ó Cofaigh, C., Bentley, M. J., and Evans, D. J. A.: Glacial history of sub-Antarctic South Georgia based on the submarine geomorphology of its fjords, Quaternary Sci. Rev., 89, 129-147, 2014.

Howat, I. M. and Domack, E. W.: Reconstructions of western Ross Sea palaeo-ice-stream grounding zones from high-resolution acoustic stratigraphy, Boreas, 32, 56-75, 2003.

Jamieson, S. S. R., Vieli, A., Livingstone, S. J., Ó Cofaigh, C., Stokes, C., Hillenbrand, C. D., and Dowdeswell, J. A.: Icestream stability on a reverse bed slope, Nat. Geosci., 5, 799-802, https://doi.org/10.1038/NGEO1600, 2012.

Joughin, I., Howat, I. M., Fahnestock, M., Smith, B., Krabill, W., Alley, R. B., Stern, H., and Truffer, M.: Continued evolution of Jakobshavn Isbrae following its rapid speedup, J. Geophys. Res., 113, F04006, https://doi.org/10.1029/2008JF001023, 2008.

King J. C., Turner, J., Marshall G. T., Connelley, W. M., and Lachlan-Cope, T. A.: Antarctic Peninsula climate variability and its causes as revealed by analysis of instrumental records. In Antarctic Peninsula climate variability, Domack, E, American Geophysical Union, Washington, DC, 2003.

Klages, J. P., Kuhn, G., Hillenbrand, C. D., Graham, A. G. C., Smith, J. A., Larter, R. D., and Gohl, K.: First geomorphological record and glacial history of an inter-ice stream ridge on the West Antarctic continental shelf, Quaternary Sci. Rev., 61, 4761, https://doi.org/10.1016/j.quascirev.2012.11.007, 2013.

KOPRI: Annual report of environmental monitoring on human impacts around the King Sejong Station, Antarctica, Korea Polar Research Institute, Incheon, South Korea, Report, No. BSE 413040-1-11, 2014.

Kuhn, G., Hillenbrand, C. D., Kasten, S. Smith, J. A., Nitsche, F. O., Frederichs, T., Wiers, S., Ehrmann, W., Klages, J. P., and Mogollon, J. M: Evidence for a palaeo-subglacial lake on the Antarctic continental shelf, Nat. Commun., 8, 15591, https://doi.org/10.1038/ncomms15591, 2017.

Larter, R. D., Graham, A. G. C., Gohl, K., Kuhn, G., Hillenbrand, C. D., Smith, J. A., Deen, T. J., Livermore, R. A., and Schenke, H. W.: Subglacial bedforms reveal complex basal regime in a zone of paleo-ice stream convergence, Amundsen Sea Embayment, West Antarctica, Geology, 37, 411-414, 2009.

Lavoie, C., Domack, E. W., Pettit, E. C., Scambos, T. A., Larter, R. D., Schenke, H.-W., Yoo, K. C., Gutt, J., Wellner, J., Canals, M., Anderson, J. B., and Amblas, D.: Configuration of the Northern Antarctic Peninsula Ice Sheet at LGM based on a new synthesis of seabed imagery, The Cryosphere, 9, 613-629, https://doi.org/10.5194/tc-9-613-2015, 2015.

Lee, J., Jin, Y. K., Hong, J. K., Yoo, H. J., and Shon, H.: Simulation of a tidewater glacier evolution in Marian Cove, King George Island, Antarctica, Geosci. J., 12, 33-39, https://doi.org/10.1007/s12303-008-0005-x, 2008.

Livingstone, S. J., Ó Cofaigh, C., Stokes, C. R., Hillenbrand, C. D., Vieli, A., and Jamieson, S. S. R.: Glacial geomorphology of Marguerite Bay palaeo-ice stream, western Antarctic Peninsula, J. Maps, 9, 558-572, https://doi.org/10.1080/17445647.2013.829411, 2013. 
Lowe, A. L. and Anderson, J. B.: Reconstruction of the West Antarctic ice sheet in Pine Island Bay during the Last Glacial Maximum and its subsequent retreat history, Quaternary Sci. Rev., 21, 1879-1897, 2002.

Milliken, K. T., Anderson, J. B, Wellner, J. S., Bohaty, S. M., and Manley, P. L.: High resolution Holocene climate record from Maxwell Bay, South Shetland Islands, Antarctica, Geol. Soc. Am. Bull., 121, 1711-1725, 2009.

Monien, P., Schnetger, B., Brumsack, H. J., Hass, H. C., and Kuhn, G.: A geochemical record of late Holocene palaeoenvironmental changes at King George Island (maritime Antarctica), Antarct. Sci., 23, 255-267, https://doi.org/10.1017/S095410201100006X, 2011.

Moon, H. W., Wan Hussin, W. M. R., Kim, H. C., and Ahn, I. Y.: The impacts of climate change on Antarctic nearshore egaepifaunal benthic assemblages in a glacial fjord on King George Island: Responses and implications, Ecol. Indic., 57, 280-292, 2015.

Morris, E. M. and Vaughan, D. G.: Spatial and temporal variation of surface temperature on the Antarctic Peninsula and the limit of variability of ice shelves, Antarct. Res. Ser., 79, 61-68, 2003.

Munoz, Y. P. and Wellner, J. S.: Local controls on sediment accumulation and distribution in a fjord in the West Antarctic Peninsula: implications for palaeoenvironmental interpretations, Polar Res., 35, 25284, https://doi.org/10.3402/polar.v35.25284, 2016.

Nitsche, F. O., Gohl, K., Larter, R. D., Hillenbrand, C.-D., Kuhn, G., Smith, J. A., Jacobs, S., Anderson, J. B., and Jakobsson, M.: Paleo ice flow and subglacial meltwater dynamics in Pine Island Bay, West Antarctica, The Cryosphere, 7, 249-262, https://doi.org/10.5194/tc-7-249-2013, 2013.

Ó Cofaigh, C. and Dowdeswell, J. A.: Laminated sediments in glacimarine environment: diagnostic criteria for their interpretations, Quaternary Sci. Rev., 20, 1411-1436, 2001.

Ó Cofaigh, C., Pudsey, C. J., Dowdeswell, J. A., and Morris, P.: Evolution of subglacial bedforms along a paleo-ice stream, Antarctic Peninsula continental shelf, Geophys. Res. Lett., 29, 1199, https://doi.org/10.1029/2001GL014488, 2002.

Ó Cofaigh, C., Larter, R. D., Dowdeswell, J. D., Hillenbrand, C. D., Pudsey, C. J., Evans, J., and Morris, P.: Flow of the West Antarctic Ice Sheet on the continental margin of the Bellingshausen Sea at the Last Glacial Maximum, J. Geophys. Res., 110, B11103, https://doi.org/10.1029/2005JB003619, 2005.

Ó Cofaigh, C., Davies, B. J., Livingstone, S. T., Smith, J. A., Johnson, J. S., Hocking, E. P., Hodgson, D. A., Anderson, J. B., Bentley, M. J., Canals, M., Domack, E., Dowdeswell, J. D., Evans, J., Glasser, N. F., Hillenbrand, C. D., Larter, R. D., Roberts, S. J., and Simms, A.: Reconstruction of ice-sheet changes in the Antarctic Peninsula since the Last Glacial Maximum, Quaternary Sci. Rev., 100, 87-110, 2014.

O'Neel, S., Pfeffer, W. T., Krimmel, R., and Meier, M.: Evolving force balance a Columbia Glacier, Alaska, during its rapid retreat, J. Geophys. Res., 110, F03012, https://doi.org/10.1029/2005JF000292, 2005.

Ottesen, D. and Dowdeswell, J. A.: Assemblages of submarine landforms produced by tidewater glaciers in Svalbard, J. Geophys. Res., 111, F01016, https://doi.org/10.1029/2005JF000330, 2006.
Ottesen, D. and Dowdeswell, J. A.: An inter-ice-stream glaciated margin: Submarine landforms and a geomorphic model based on marine geophysical data from Svalbard, Geol. Soc. Am. Bull., 121, 1647-1665, https://doi.org/10.1130/B26467.1, 2009.

Ottesen, D., Dowdeswell, J. A., and Rise, L.: Submarine landforms and the reconstruction of fast-flowing ice streams within a large Quaternary ice sheet: The 2500-km-long NorwegianSvalbard margin $\left(57^{\circ}-80^{\circ} \mathrm{N}\right)$, Geol. Soc. Am. Bull. 117, 10331050, https://doi.org/10.1130/B25577.1, 2005.

Pereira, T. T. C., Schaefer, C. E. G. R., Ker, J. C., Almeida, C. C., Almeida, I. C. C., and Pereira, A. B.: Genesis, mineralogy and ecological significance of ornithogenic soils from a semi-desert polar landscape at Hope Bay, Antarctic Peninsula, Geoderma, 209-210, 98-109, https://doi.org/10.1016/j.geoderma.2013.06.012, 2013.

Powell, R. D.: A model for sedimentation by tidewater glaciers, Ann. Glaciol., 2, 129-134, 1981.

Powell, R. D. and Domack, E. W.: Modern glaciomarine environments, in: Modern glacial environments: processes, dynamics, and sediments, edited by: Menzies, J., Boston, ButterworthHeinmann, 445-486, 1995.

Robel, A. A.: Thinning sea ice weakens buttressing force of iceberg melange and promotes calving, Nat. Commun., 8, 14596, https://doi.org/10.1038/ncomms14596, 2017.

Ruckamp, M., Braun, M., Suckro, S., and Blindow, N.: Observed glacial changes on the King George Island ice cap, Antarctica, in the last decade, Global Planet. Change, 79, 99-109, https://doi.org/10.1016/j.gloplacha.2011.06.009, 2011.

Schaefer, C. E. G. R., Pereira, T. T. C., Almeida, I. C. C., Michel, R. F. M., Correa, G. R., Figueiredo, L. P. S., and Ker, J. C.: Penguin activity modify the thermal regime of active layer in Antarctica: A case study from Hope Bay, Catena, 149, 582-591, https://doi.org/10.1016/j.catena.2016.07.021, 2016.

Shevenell, A. E., Domack, E. W., and Kernan, M.: Record of Holocene palaeoclimate change along the Antarctic Peninsula: evidence from glacial marine sediments, Lallemand Fjord, Papers and Proceedings of the Royal Society of Tasmania, 130, 55-64, 1996.

Simms, A. R., Milliken, K. T., Anderson, J. B., and Wellner, J. S.: The marine record of deglaciation of the South Shetland Islands, Antarctica since the Last Glacial Maximum, Quaternary Sci. Rev., 30, 1583-1601, https://doi.org/10.1016/j.quascirev.2011.03.018, 2011.

Simms, A. R., Ivins, E. R., DeWitt, R., Kouremenos, P., and Simkins, L. M.: Timing of the most recent Neoglacial advance and retreat in the South Shetland Islands, Antarctic Peninsula, insights from raised beaches and Holocene uplift rates, Quaternary Sci. Rev., 47, 41-55, https://doi.org/10.1016/j.quascirev.2012.05.013, 2012.

Syvitski, J. P. M., Burrell, D. C., and Skei, J. M.: Fjords: processes and products, Springer, Berlin, 1987.

Thomas, E. R., Marshall, G. J., and McConnell, J. R.: A doubling in snow accumulation in the western Antarctic Peninsula since 1850, Geophys. Res. Lett., 35, L01706, https://doi.org/10.1029/2007GL032529, 2008

Turner, J., Lu, H., White, I., King, J. C., Phillips, T., Hosking, J. S., Bracegirdle, T. J., Marshall, G. J., Mulvaney, R., and Deb, P.: Absence of $21^{\text {st }}$ century warming on Antarctic Peninsula consistent with natural variability, Nature Letter, 535, 411-415, 2016. 
Wellner, J. S., Lowe, A. L., Shipp, S. S., and Anderson, J. B.: Distribution of glacial geomorphic features on the Antarctic continental shelf and correlation with substrate: implications for ice behavior, J. Glaciol., 47, 397-411, https://doi.org/10.3189/172756501781832043, 2001.

Wellner, J. S., Heroy, B. C., and Anderson, J. B.: The death mask of the Antarctic ice sheet: comparison of glacial geomorphic features across the continental shelf, Geomorphology, 75, 157-171, https://doi.org/10.1016/j.geomorph.2005.05.015, 2006.

Whillans, I. M. and van deer Veen, C. J.: The role of lateral drag in the dynamics of Ice Stream B, Antarctica, J. Glaciol., 43, 231237, 1997.
Wölfl, A. C., Lim, C .H., Hass, H. C., Lindhorst, S., Tosonotto, G., Lettmann, K. A., Kuhn, G., Wolff, J. O., and Abele, D.: Distribution and characteristics of marine habitats in a subpolar bay based on hydroacoustics and bed shear stress estimates - Potter Cove, King George Island, Antarctica, Geo-Mar. Lett., 34, 435446, https://doi.org/10.1007/s00367-014-0375-1, 2014.

Wölfl, A. C., Wittenberg, N., Feldens, P., Hass, H. C., Betzler, C., and Kuhn, G.: Submarine landforms related to glacier retreat in a shallow Antarctic fjord, Antarct. Sci., 28, 475-486, https://doi.org/10.1017/S0954102016000262, 2016.

Yoon, H. I., Yoo, K. C., Park, B. K., Kim, Y., Khim, B. K., and Kang, C. Y.: The origin of massive diamicton in Marian and Potter coves, King George Island, West Antarctica, Geosci. J., 8, $1-10,2004$. 